\title{
Methods of synthesis of cyclobutenediones
}

\author{
Amere Mukkanti and Mariappan Periasamy* \\ School of Chemistry, University of Hyderabad, Central University P. O., India 500046 \\ E-mail: mpsc@uohyd.ernet.in
}

\section{Dedicated to Professor S. Swaminathan on the occasion of his $80^{\text {th }}$ birthday}

(received 17 Sept 04; accepted 28 Oct 04; published on the web 10 Nov 04)

\begin{abstract}
Cyclobutenediones have been used as versatile starting materials for the synthesis of a wide range of multifunctional molecules. There have been continued efforts to develop general and practical methods to access the cyclobutenediones, which led to the discovery of several new methodologies over the last two decades. A review of various methods of synthesis of cyclobutenediones is presented.
\end{abstract}

Keywords: Cyclobutenediones, squaric acid, squarates, benzocyclobutenediones, cycloadditions and double carbonylations

\section{Introduction}

Cyclobutenediones are considered as quinones of unstable cyclobutadienes because of their formal resemblance to cyclobutadienes by virtue of all $\mathrm{sp}^{2}$ hybridised carbons in a four membered ring. ${ }^{1}$ Phenylcyclobutenedione was the first cyclobutenedione to be synthesized by J. D. Roberts et al. ${ }^{\text {la }}$ in 1955 . The initial studies on cyclobutenediones were limited primarily to their unusual stability, ${ }^{1}$ reactivity toward nucleophiles ${ }^{2}$ and aromaticity of their oxoanions. ${ }^{3}$ Extraction of moniliformin 1a, a fungal toxin, from Fusarium moniliforme by Cole et al. ${ }^{4}$ led to the synthesis and testing of wide range of cyclobutenediones. Subsequently, a number of biological and pharmaceutical applications of cyclobutenediones were discovered. For example, the di-n-butylsquarate $1 \mathrm{c}\left(\mathrm{R}=n-\mathrm{C}_{4} \mathrm{H}_{9}\right)$ is a potent allergen and has been used in the treatment of alopecia areata, and in immunotherapy for warts in children. ${ }^{5}$ Squaric acid $1 c(R=H)$ itself is an inhibitor of glyoxylase I, ${ }^{6 a}$ semisquaric acid $\mathbf{1 b}$ is an inhibitor for pyruvate dehydrogenase and transketolase $^{6 \mathrm{a}}$ and 1d is an inhibitor for PTPases (protein tyrosine phosphatases). ${ }^{6 \mathrm{c}}$ Recently, the diamide of squaric acid 1e was used as a replacement for one of the phosphate diester linkages in an oligodeoxynucleotide, ${ }^{7}$ while 1f as antagonist of the NMDA (N-methyl-D-aspartate) 
receptor. ${ }^{8}$ Also, some of the cyclobutenedione derivatives are useful as high-affinity ligands for exitatory amino acid receptors ${ }^{9}$ and anion recognition systems. ${ }^{10}$

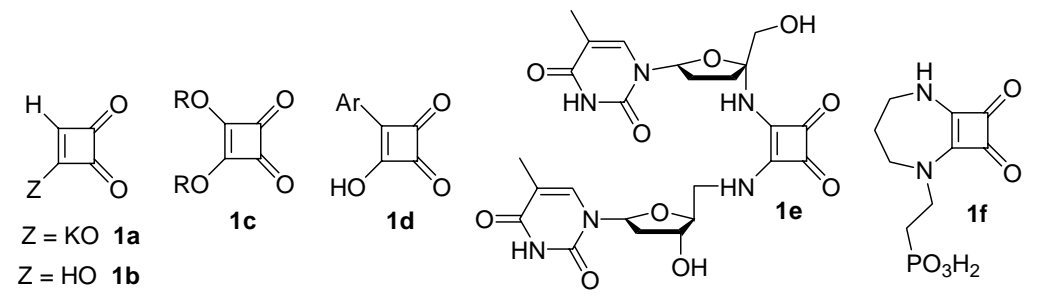

Extensive studies by Liebeskind, ${ }^{11}$ Moore, ${ }^{12}$ Paquette ${ }^{13}$ and others ${ }^{14}$ have shown that cyclobutenediones are highly versatile starting materials for the synthesis of an array of multifunctional carbocyclic and heterocyclic compounds. Recently, squarate diamides have been used in the construction of chiral auxiliaries. ${ }^{15}$ Also, cyclobutenedione derivatives (squaraines) are used as NLO materials ${ }^{16}$ and photoconductors. ${ }^{17}$

Methods of synthesis of cyclobutenediones reported before 1980 were already reviewed. ${ }^{2}$ Accordingly, in this review emphasis is on the methods developed in the last 2 decades. The methods of discussion are arranged under the following topics.

1. Cyclobutenediones by thermal or photochemical cycloadditions

1.1. Cycloadditions involving alkynes

1.1.1. Addition of alkynes to tetrahaloalkenes

1.1.2. Addition of alkynes to dichlorovinylene carbonate

1.1.3. Addition of alkynes to ketenes

1.1.4. Alkyne dimerization

1.2. Cycloadditions involving alkenes

1.2.1. Addition of electron-rich olefins to electron-poor olefins

1.2.2. Addition of electron-rich olefins to ketenes

1.2.3. Addition of thioenol ethers to ketenes

1.2.4. Cyclodimerisation of tetrahaloethylenes

1.2.5. Cyclodimerisation of chlorovinylene carbonate

1.2.6. Intramolecular cycloaddition of olefins

1.2.7. Addition of dienes to olefins

2. Cyclobutenediones via transition metal complexes

3. Cyclobutenediones from cyclopropene derivatives

4. Cyclobutenediones from other simple cyclobutenediones

4.1. Halogen derivatives of cyclobutenedione

4.2. Alkoxy derivatives of cyclobutenedione

4.3. Thionyl and selenyl derivatives of cyclobutenedione

4.4. Amino derivatives of cyclobutenedione

4.5. Phosphine derivatives of cyclobutenedione

4.6. Alkyl, alkenyl, alkynyl and aryl derivatives of cyclobutenedione

5. Benzocyclobutenediones 


\section{Cyclobutenediones by thermal or photochemical cycloadditions}

\subsection{Cycloadditions involving alkynes}

1.1.1. Addition of alkynes to tetrahaloalkenes. Cycloaddition reactions between fluoroalkenes and substituted acetylenes have proven to be of considerable value in the synthesis of cyclobutenediones. $^{18}$ For example, the first reported cyclobutenedione, i.e. phenylcyclobutenedione 2 , was prepared by cycloaddition of chlorotrifluoroethylene or tetrafluoroethylene to phenylacetylene to form tetrahalogenated phenylcyclobutene. The resulting tetrahalogenated phenylcyclobutene was subjected to acid hydrolysis either directly (Path a) or via dihalogenated phenylcyclobutenone (Path b) to provide cyclobutenediones (Scheme 1). ${ }^{\text {la }}$
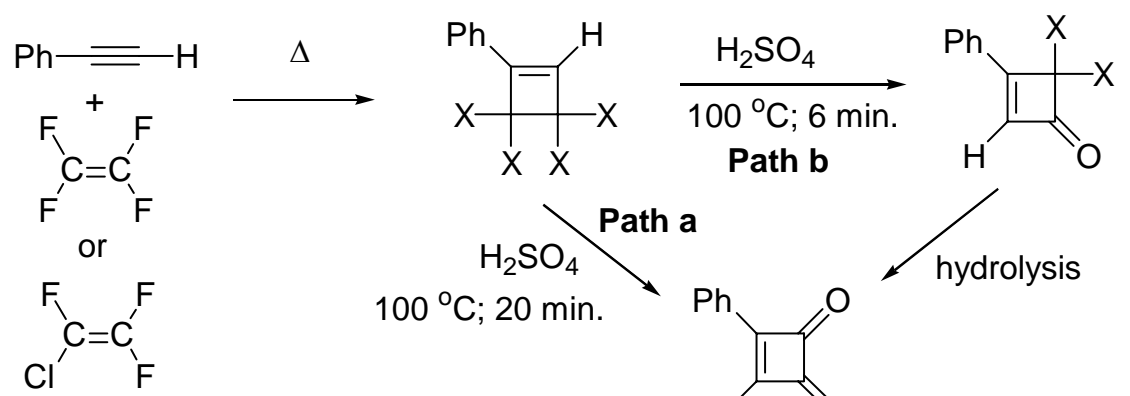

\section{Scheme 1}

$100{ }^{\circ} \mathrm{C} ; 20 \mathrm{~min}$.

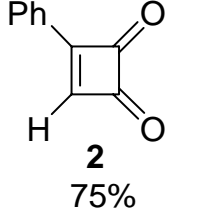

1.1.2. Addition of alkynes to dichlorovinylene carbonate. Irradiation of a mixture of dichlorovinylene carbonate (DCVC) 3 and alkyne in polar aprotic solvents like acetone or acetonitrile in the presence of photo-sensitizers gives cycloadduct 4 in poor yields $10-15 \%$. Subsequent hydrolysis of adduct at $60{ }^{\circ} \mathrm{C}$ in $60 \%$ acetone/water yields the corresponding cyclobutenediones (Scheme 2). ${ }^{19}$

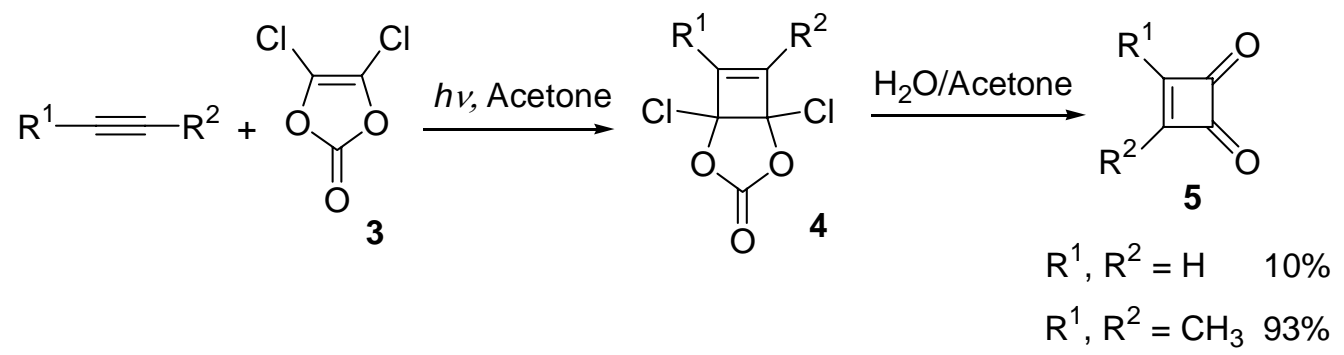

\section{Scheme 2}


1.1.3. Addition of alkynes to ketenes. Thermal cycloaddition of alkynes to dichloroketene followed by acid hydrolysis of the resulting cylobutenone affords cyclobutenediones (Scheme $3) .^{20}$
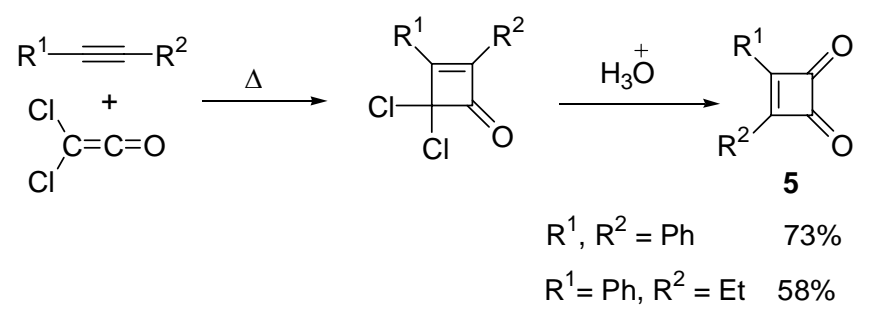

\section{Scheme 3}

1.1.4. Alkyne dimerisation. 3 -Hydroxycyclobutene-1,2-dione (semisquaric acid) $\mathbf{1 b}$, the parent compound of the natural mycotoxin "moniliformin" has been synthesized by thermal dimerisation of di-t-butoxyethyne followed by solvolysis of $\mathbf{6}$ using trifluroacetic acid (Scheme 4). ${ }^{21}$

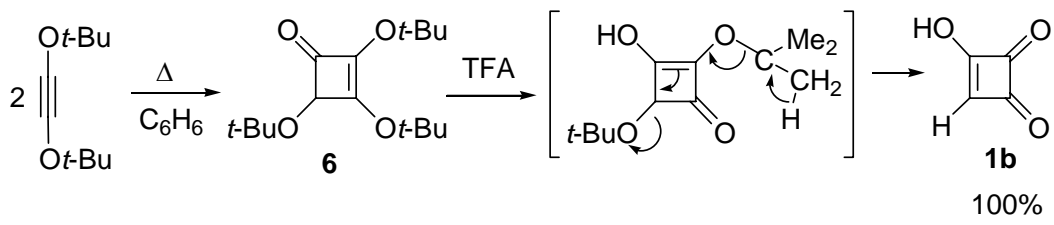

\section{Scheme 4}

\subsection{Cycloadditions involving alkenes}

1.2.1. Addition of electron-rich olefins to electron-poor olefins. Tetraalkoxy ethylene, an electron-rich olefin, adds on to electron-poor ethylene derivatives under thermal conditions to form 1,1,2,2-tetraalkoxy-3,3-dicyano-4-arylcyclobutene 7a, which upon base catalysed elimination of $\mathrm{HCN}$ gives $\mathbf{7 b}$. The 3-cyanocyclobutenedione $\mathbf{7}$ is obtained by hydrolysis of acetal groups using concentrated sulphuric acid at $25^{\circ} \mathrm{C}$ (Scheme 5). ${ }^{2 \mathrm{a}, 22}$

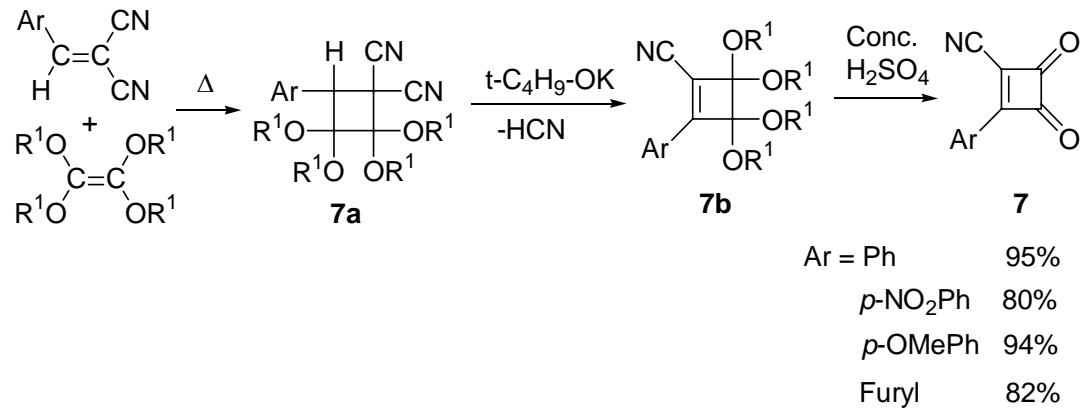

\section{Scheme 5}


1.2.2. Addition of electron-rich olefins to ketenes. An improved synthesis of cyclobutenediones and derivatives of semisquaric acid was achieved by $(2+2)$ cycloaddition of the tetraalkoxyethylenes with alkylketene, ${ }^{23 a}$ chloroketene, $^{23 \mathrm{~b}}$ oxy ketene ${ }^{23 \mathrm{c}}$ or trimethylsilyl ketene ${ }^{23 \mathrm{~d}}$ produced in situ by triethylamine-promoted dehydrohalogenation of the corresponding acyl chlorides (Scheme 6).

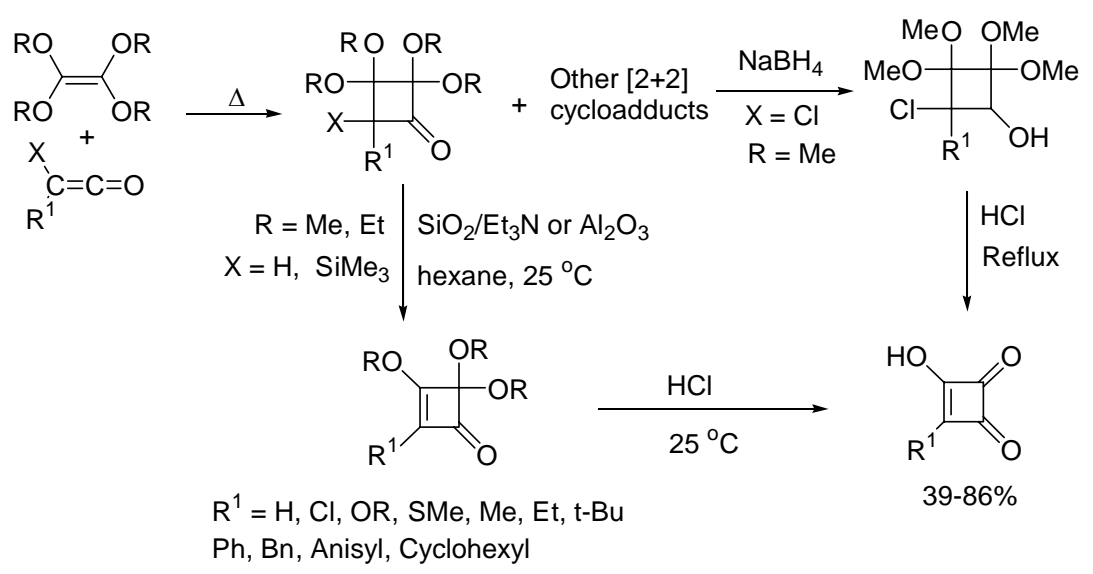

\section{Scheme 6}

Also, cycloaddition of 2,3-dihydro-1,4-dioxane to dichloroketene by sonication followed by hydrolysis leads to semisquaric acid (Equation 1). ${ }^{23 \mathrm{f}}$

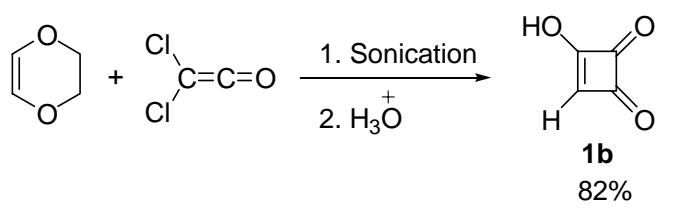

1.2.3. Addition of thioenol ethers to ketenes. Recently, Liebeskind et al. ${ }^{24}$ reported a relatively simple protocol for the synthesis of monocyclic and bicyclic cyclobutenediones starting from ketones (Scheme 7). Phenylthioenol ethers, prepared from ketones undergo regiospecific [2+2] cycloaddition with dichloroketone to provide dichlorocyclobutanone 8a, which upon $\mathrm{Et}_{3} \mathrm{~N} / \mathrm{CH}_{3} \mathrm{CN}$ treatment produces rearranged product $\mathbf{8 b}$ through $\mathrm{HCl}$ elimination. Reaction of $\mathbf{8 b}$ with $m$-chloroperbenzoic acid gives the corresponding cyclobutenedione.

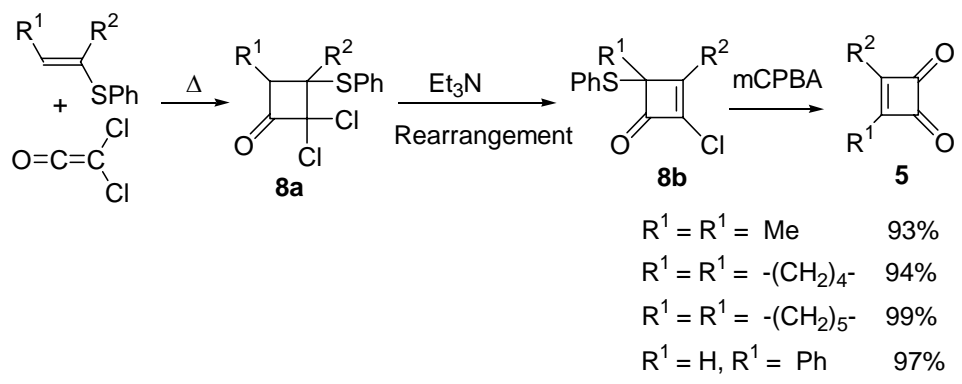

\section{Scheme 7}


1.2.4. Cyclodimerisation of tetrahaloethylenes. Heating of fluorinated ethylenes leads to stable cyclobutane rings 9a in contrast to other halogenated olefins (chloro and bromo) which give polymerised products. ${ }^{25}$ The cyclisation process is exclusively a "head to head"or "tail to tail" joining to form only one isomer. Dechlorination of 9a with $\mathrm{Zn}$ affords cyclobutene 9b, which upon further reaction with aryl lithium reagents provides 3,4-diarylcyclobutene-1,2-dione after hydrolysis (Scheme 8). Squaric acid 1c was first synthesized in 1959 by Cohen et al. ${ }^{25 a}$ following a similar procedure .
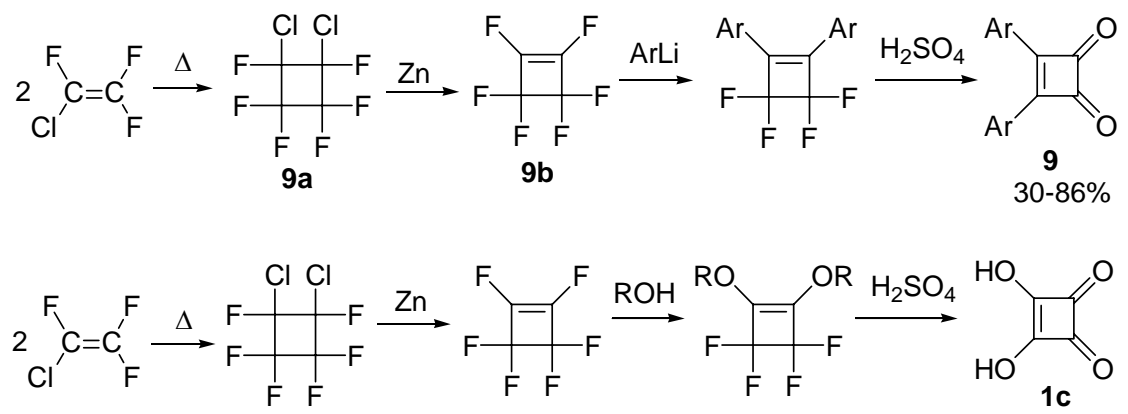

\section{Scheme 8}

1.2.5. Cyclodimerisation of chlorovinylene carbonate. Both mono and dichlorovinylene carbonates undergo dimerisation upon irradiation in acetone solution to form cyclobutanes 10a and 10b, respectively. Hydrolysis of the adduct 10a yields hydroxycyclobutenedione 1b, whereas the 10b gives octahydrocyclobutane 10c, which on reaction with $\mathrm{SO}_{2}$ yields squaric acid 1c (Scheme 9). ${ }^{26}$
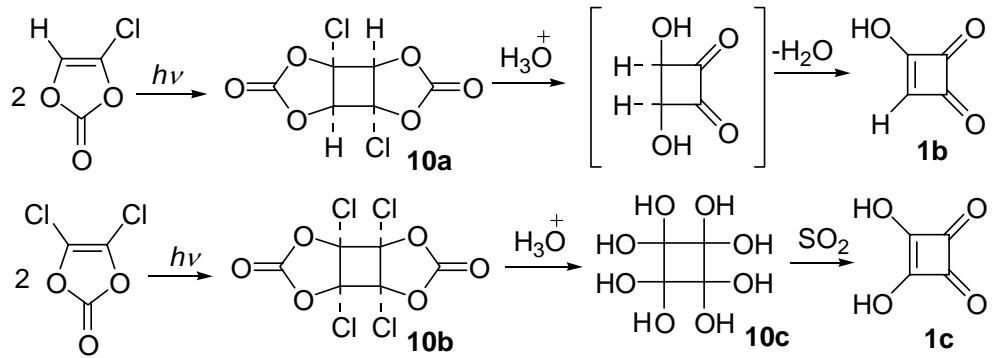

\section{Scheme 9}

1.2.6. Intramolecular cycloaddition of olefins. Allenes of the type 11a undergo intramolecular [2+2] cycloaddition under thermal conditions to form 1,2-dibromo-3,4bis(diphenylmethylene)cyclobutene 11b which on photo-oxidation affords 3,4bis(bromodiphenylmethyl)cyclobutene-1,2-dione 11 (Path a) ${ }^{27 b}$ (Scheme 10). Alternatively, it can be converted to stable, isolable cyclobutene epoxide 11c by refluxing with potassium alkoxide (Path b). Acid catalysed photochemical ring opening of 11c gives 3-diphenylmethyl-4bromodiphenylmethylcyclobutene-1,2-dione 12 in quantitative yields. ${ }^{27 a}$ 


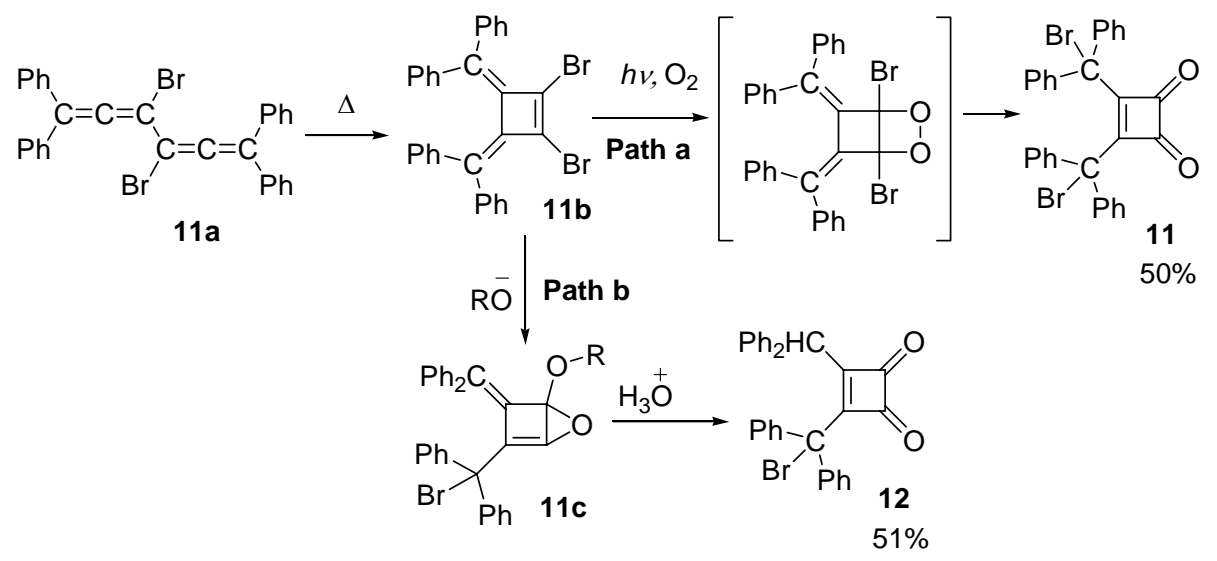

\section{Scheme 10}

1.2.7. Addition of dienes to olefins. Substituted benzocyclobutenediones 14 have been prepared by utilizing Diels-Alder chemistry. Cycloaddition of trimethylsiloxy dienes to 1,4-dichloro3,3,4-triflurocyclobutene 13 gives the cycloadduct 13a that on aromatisation followed by acid hydrolysis gives benzocyclobutenediones (Scheme 11). ${ }^{28}$

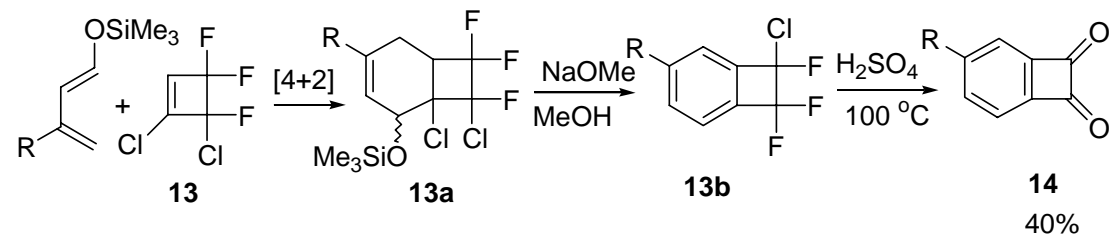

\section{Scheme 11}

Diels-Alder reaction of 3-chloro-3-cyclobutene-1,2-dione with dienes gives the adduct 15a, which upon oxidation by active $\mathrm{MnO}_{2}$ produces benzocyclobutenediones 15 (Scheme 12). ${ }^{29}$

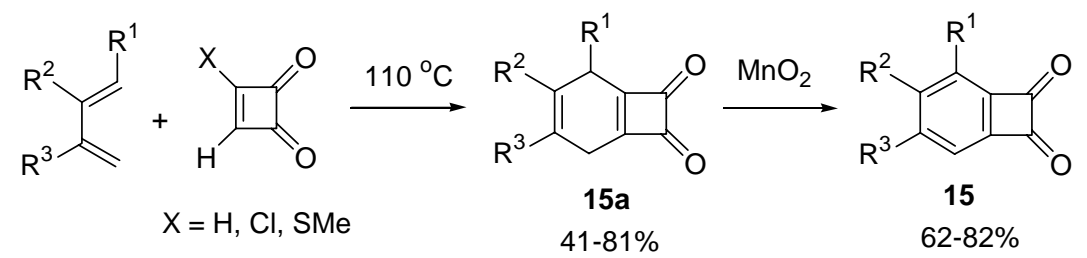

\section{Scheme 12}

Similarly, tetrachlorobenzocyclobutenedione $\mathbf{1 6}$ has been prepared via dimerisation of perchlorobutenyne 16a followed by acid hydrolysis (Scheme 13). ${ }^{30}$ 


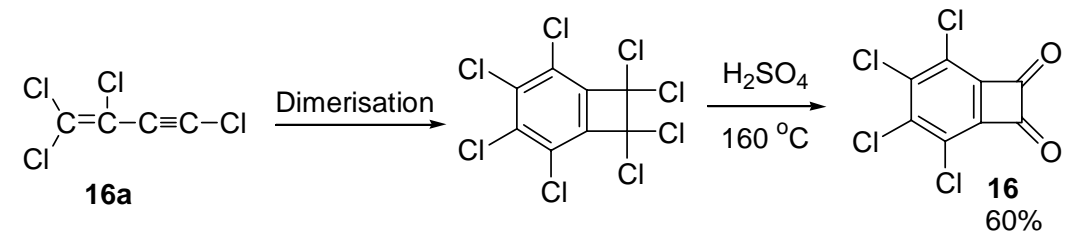

\section{Scheme 13}

\section{Cyclobutenediones via transition metal complexes}

Thermal reaction of alkynylalkoxycarbene complexes of chromium 17a and tungsten 17b with tetraalkoxyethylene affords good yields of [2+2] cycloadducts under mild conditions. The release of organic ligand from metal carbonyl was achieved by DMSO oxidation, and the resulting cyclobutene 18b gives differently substituted cyclobutenediones 18 upon $\mathrm{H}_{2} \mathrm{SO}_{4}$ or $\mathrm{CF}_{3} \mathrm{COOH}$ hydrolysis (Scheme 14). ${ }^{31}$

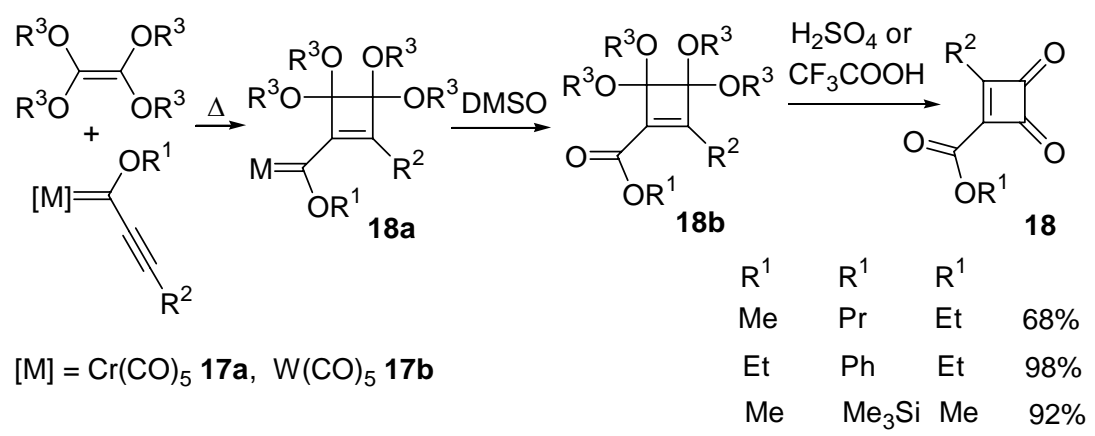

\section{Scheme 14}

Palladium chloride induced cyclodimerization of di-t-butoxyethyne leads directly to di-tbutyl squarate $1 \mathrm{c}\left(\mathrm{R}=t-\mathrm{C}_{4} \mathrm{H}_{9}\right)$ via intramolecular $t$ - BuCl elimination (Scheme 15$) .{ }^{21}$

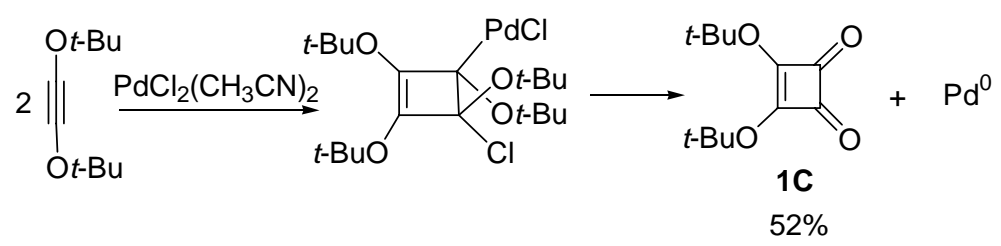

\section{Scheme 15}

A novel cycloaddition of nickel complex to alkyne was reported. It was found that an equimolar ratio of tetrakis(arylisocyanide)nickel and diphenylacetylene upon refluxing in toluene yielded di-iminocyclobutene 19, which after aqueous $\mathrm{HCl}$ work up gave diphenylcyclobutenedione (Scheme 16). ${ }^{32}$ 


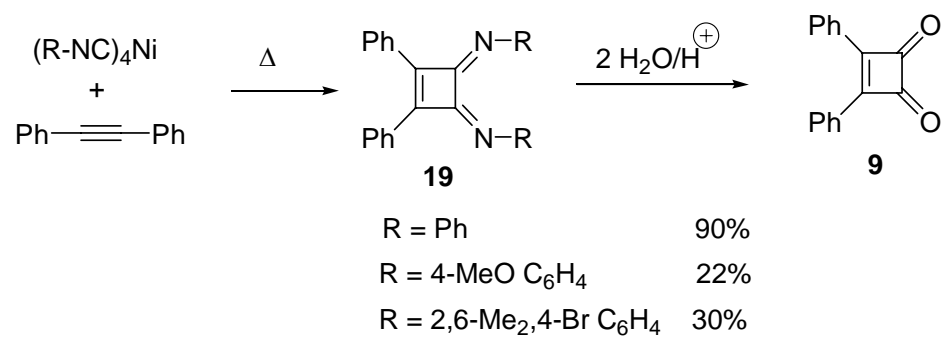

\section{Scheme 16}

Oxidation of tetrakis(diethylamino)cyclopentadienone $\mathbf{2 0}$ with bromine and aqueous work up affords a novel cyclobutenedione with an interesting functionality $22 .{ }^{33}$ Dione has also been prepared via 21 by electrochemical or nitrosonium hexafluorophosphate oxidation (Scheme $17) .^{33}$

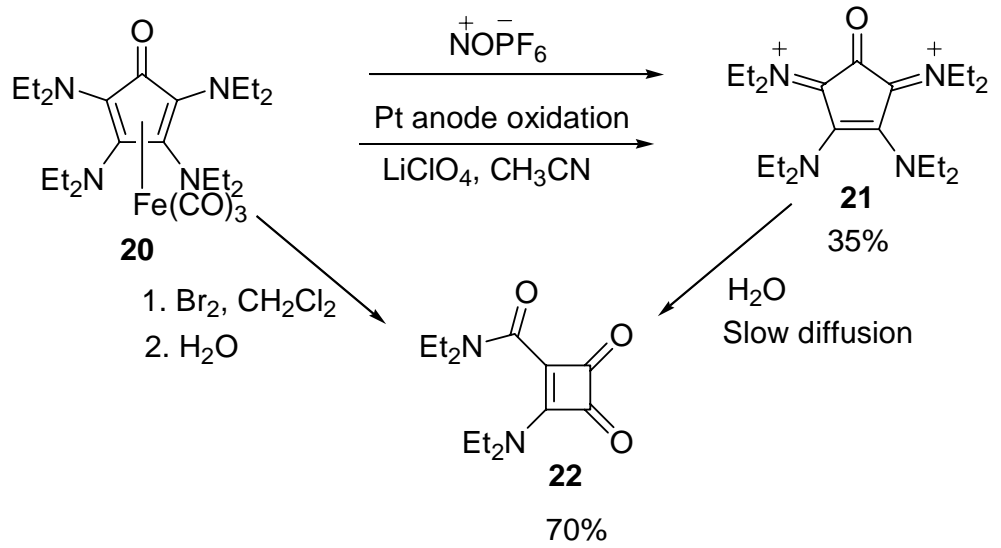

\section{Scheme 17}

It was reported that the $\mathrm{FeCl}_{3}$ oxidation of ferrole complex formed in the reaction of acetylene with an alkaline solution of $\mathrm{Fe}(\mathrm{CO})_{5}$ leads to cyclobutenedione in low yield (Scheme 18). ${ }^{34}$

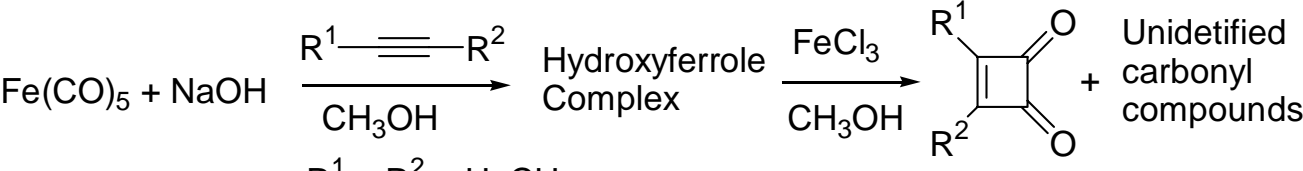

$$
\begin{aligned}
& \mathrm{R}^{1}=\mathrm{R}^{2}=\mathrm{H}, \mathrm{CH}_{3}
\end{aligned}
$$

\section{Scheme 18}

Herrera et al. ${ }^{35}$ reported that the nickelcyclopentenediones 23, prepared by reaction of (bpy)Ni(CO) $)_{2}$ with alkyne in $\mathrm{THF}$ at $20{ }^{\circ} \mathrm{C}$, affords cyclobutenediones with maleic anhydride or carbon monoxide (Scheme 19). Nickel complex 23 can also be obtained from the reaction of (bpy)Ni(alkyne) with molecular CO. ${ }^{35 \mathrm{a}}$ 

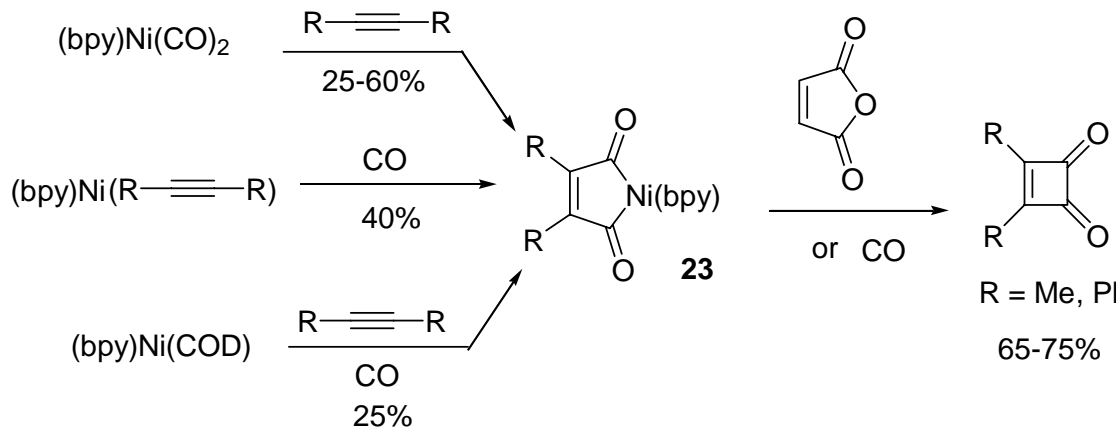

$\mathrm{R}=\mathrm{Me}, \mathrm{Ph}$

$65-75 \%$

\section{Scheme 19}

It was reported from this laboratory that the reaction of $\mathrm{NaHFe}(\mathrm{CO})_{4} / \mathrm{CH}_{3} \mathrm{I}$ reagent combination with alkynes at $60{ }^{\circ} \mathrm{C}$ gives the corresponding cyclobutenediones along with unsaturated carboxylic acids after $\mathrm{CuCl}_{2} \cdot 2 \mathrm{H}_{2} \mathrm{O}$ oxidation (Scheme 20). ${ }^{36 \mathrm{a}}$

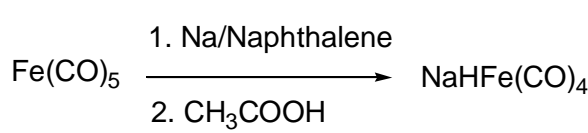

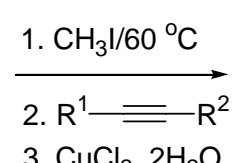

3. $\mathrm{CuCl}_{2} \cdot 2 \mathrm{H}_{2} \mathrm{O}$

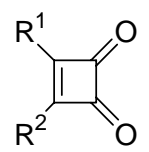

5

$27-42 \%$

\section{Scheme 20}

It was found that the reagent prepared using $\mathrm{NaHFe}(\mathrm{CO})_{4} / \mathrm{Me}_{3} \mathrm{SiCl}$ at $60{ }^{\circ} \mathrm{C}$, upon reaction with alkynes followed by $\mathrm{CuCl}_{2} \cdot 2 \mathrm{H}_{2} \mathrm{O}$ oxidation produced the corresponding cyclobutenediones $(51-63 \%)$ (Scheme 21). ${ }^{36 \mathrm{~b}}$

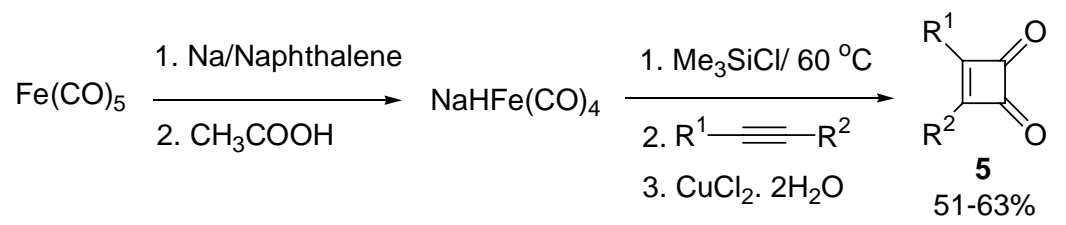

\section{Scheme 21}

Also, it was observed that the $\left[\mathrm{HFe}_{3}(\mathrm{CO})_{11}\right]^{-}$species, prepared in situ using $\mathrm{Fe}(\mathrm{CO})_{5} / \mathrm{NaBH}_{4} / \mathrm{CH}_{3} \mathrm{COOH}$, reacts with alkynes to give the corresponding cyclobutenediones in good yields (60-73\%) after $\mathrm{CuCl}_{2} \cdot 2 \mathrm{H}_{2} \mathrm{O}$ oxidation (Equation 2$){ }^{37}$

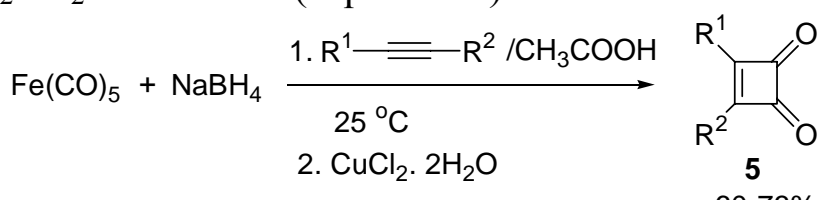

Further, it was found that the iron carbonyl species, prepared by the reduction of $\mathrm{FeCl}_{3} / \mathrm{NaBH}_{4}$ in $\mathrm{THF}$ at $25{ }^{\circ} \mathrm{C}$ in the presence of $\mathrm{CO}$, reacts with alkynes at room temperature to 
give a complex that gives the corresponding cyclobutenediones after $\mathrm{CuCl}_{2} \cdot 2 \mathrm{H}_{2} \mathrm{O}$ oxidation (Scheme 22). ${ }^{38}$

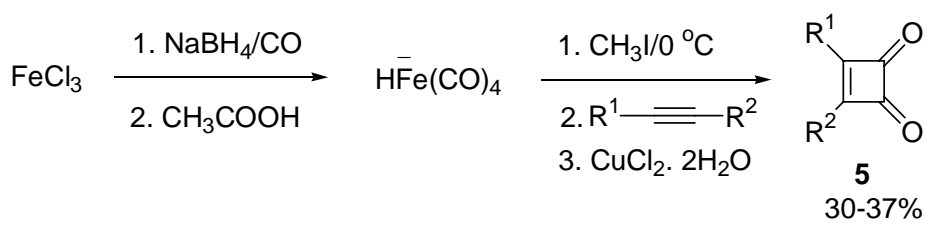

\section{Scheme 22}

Coordinatively unsaturated iron carbonyl species, prepared using $\mathrm{Fe}_{3}(\mathrm{CO})_{12}$ /amine, react with alkynes under ambient conditions to afford cyclobutenediones (Equation 3). ${ }^{39 \mathrm{a}}$

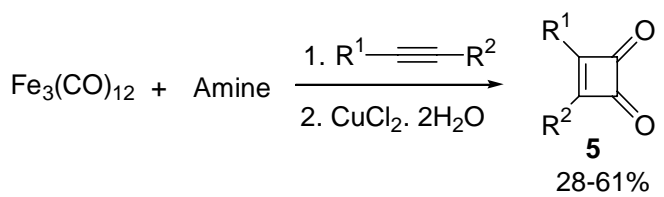

Very recently, it has been reported that cyclobutenediones are formed in good yields via bromine oxidation of acyloxyferrole complexes 24 (Equation 4). ${ }^{39 b}$

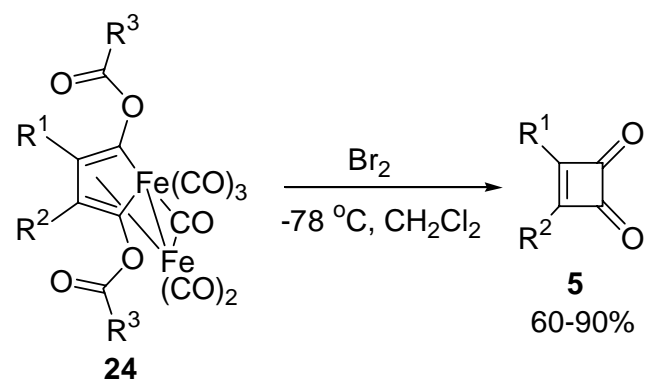

\section{Cyclobutenediones from cyclopropene derivatives}

Though, this is not a method of choice due to the difficulty associated with starting material preparation, cyclobutenediones could be obtained from cyclopropenones by ring expansion. Reaction of sodium trichloroacetate with dialkylcyclopropenone 25a under thermal conditions gives 5 via dichlorodialkylcyclobutenone (Scheme 23). ${ }^{40}$

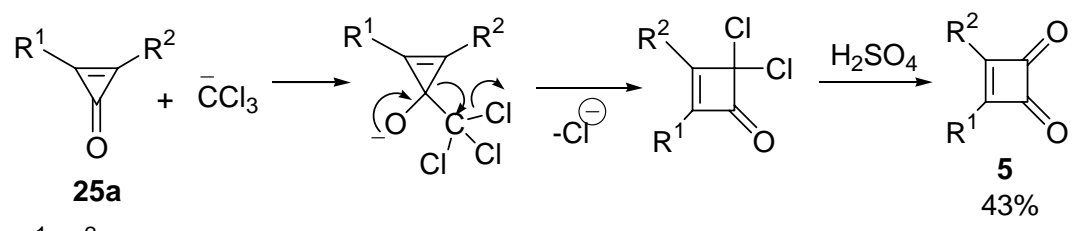

Scheme 23 
Similarly, base hydrolysis of 25b directly gives the corresponding cyclobutenedione (Equation 5). ${ }^{41}$

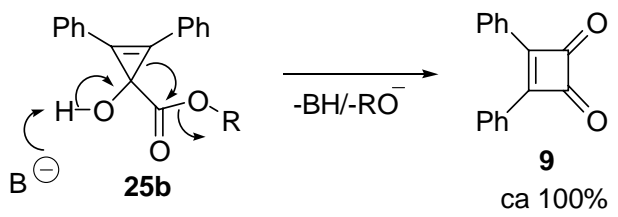

Also, it has been reported that isonitriles react with cyclopropenones to give cyclobutenedione in the presence of triphenylphosphine via iminocyclobutenone $26 .{ }^{42}$ The formation of $\mathbf{2 6}$ involves Michael addition of $\mathrm{P}(\mathrm{Ph})_{3}$ to generate ketene-phosphorane followed by concerted rearrangement of P-C bonds as shown in Scheme 24.

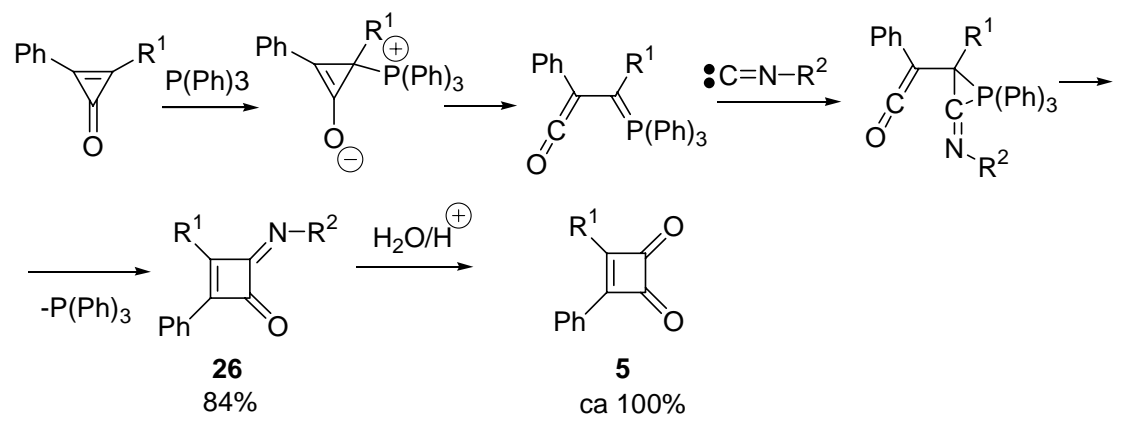

Scheme 24

\section{Cyclobutenediones from other simple cyclobutenediones}

Synthesis of cyclobutenediones based on cycloaddition reactions is limited to either to squaric acid or aryl and simple alkyl derivatives. Hence, cyclobutenediones with a wide range of substituents have been synthesized from simple diones such as ynthesi, halo or alkoxy substituted cyclobutenediones by reacting with a variety of carbon as well as hetero atom nucleophiles. The underlying principle in all these reactions is the vinylogous behaviour of cyclobutenediones i.e. ynthesi, halo and alkoxy cyclobutenediones show the reactivity similar to that of acid, acid chloride and ester, respectively (Scheme 25). ${ }^{2}$

\section{Scheme 25}

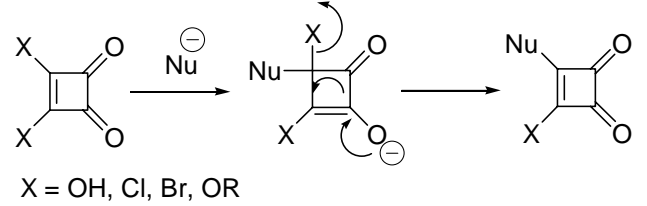




\subsection{Halogen derivatives of cyclobutenedione}

It has been reported that the reaction of squaric acid with $\mathrm{SOCl}_{2}$ in the presence of DMF leads to the replacement of both the $\mathrm{OH}$ groups to form dichlorocyclobutenedione in good yields 27 (Equation 6). ${ }^{43}$ Also, phenylcyclobutenedione is readily halogenated in glacial acetic acid (Equation 7). ${ }^{1 \mathrm{~b}}$

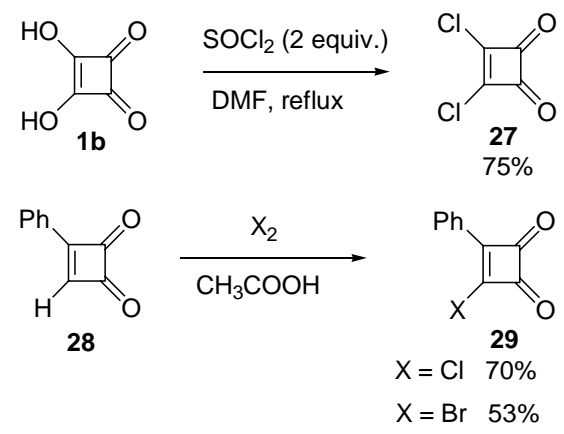

\subsection{Alkoxy derivatives of cyclobutenedione}

Alkoxy derivatives of cyclobutenedione, squaric acid esters, have been synthesized from squaric acid following different strategies as outlined in Scheme $26 .{ }^{2 \mathrm{~d}, 44}$ The chemical properties of squaric acid are mainly determined by its acid character and its reactivity is comparable to that of dicarboxylic acids. Ethyl or butyl alcohol treatment of squaric acid gives the corresponding diesters, whereas methanol gives monoester 30b. However, dimethylsquarate was synthesized by the action of diazomethane on $\mathbf{1 b}$ or by the reaction of methyl iodide with $\mathbf{3 0 d}$.

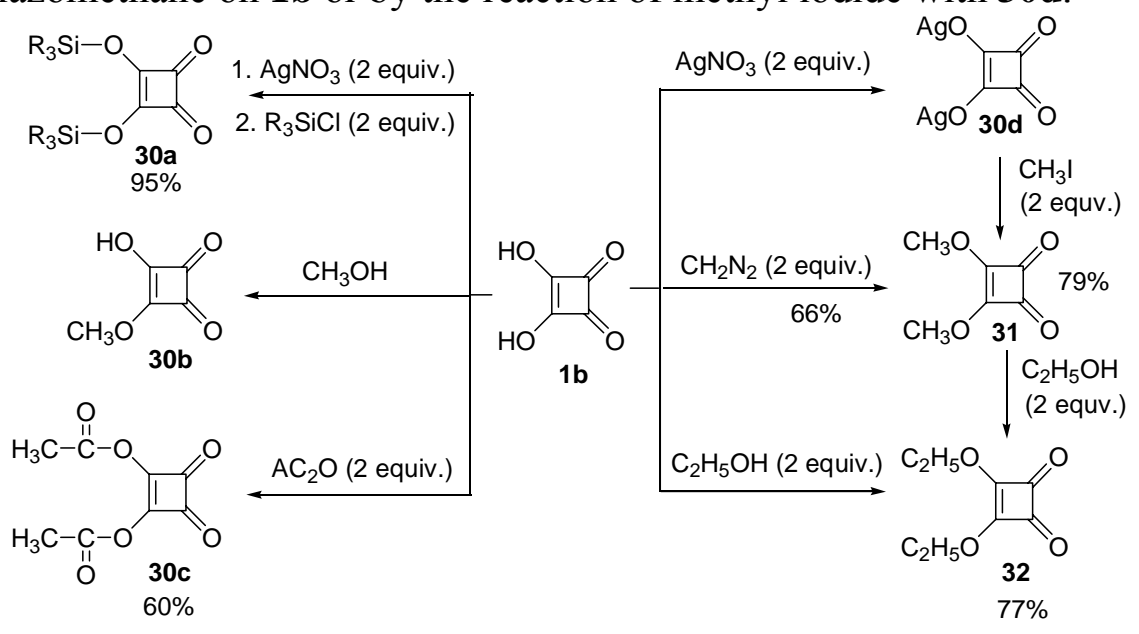

\section{Scheme 26}

A similar reaction of halocyclobutenediones with alcohols give good yields of squaric acid esters (Scheme 27). ${ }^{2 \mathrm{~b}, 44 \mathrm{~b}}$ As described later in this section, dialkoxy squarates are extensively used in the synthesis of a variety of cyclobutenediones. 

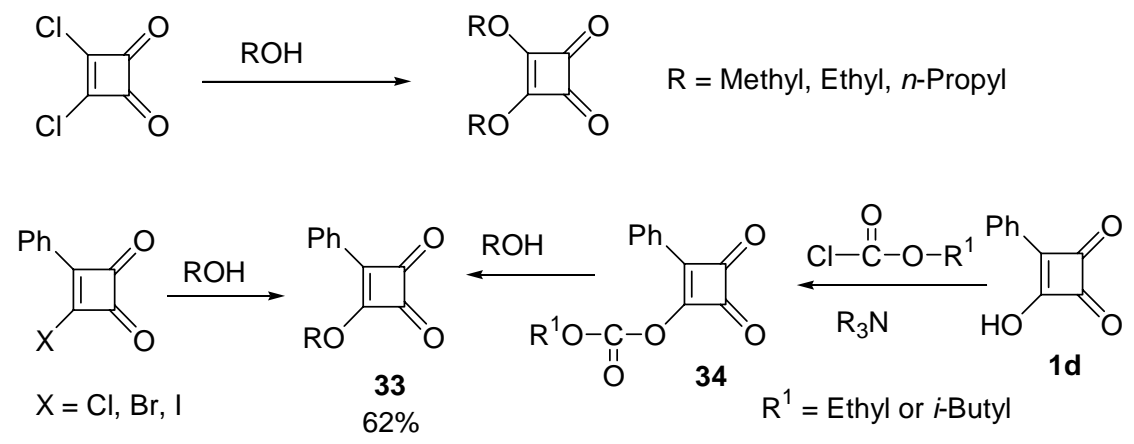

\section{Scheme 27}

\subsection{Thionyl and selenyl derivatives of cyclobutenedione}

It was reported that the reaction of diethyl squarate with 2 equiv. of sodium or potassium hydrosulfide in alcohol gives the 1,2-dithiosquarate anion $35,{ }^{45 \mathrm{a}}$ which has also been prepared from squaric acid diamide 36 in low yield (Scheme 28). ${ }^{45 a}$ Dithiosquarate anion is readily alkylated with $\mathrm{CH}_{3} \mathrm{I}$ to give dithioester 37a. Also, thioester 37b has been ynthesized by the reaction of benzylmercaptan and 3,4-dichloro-3-cyclobutene-1,2-dione in the presence of amine bases (Scheme 28). ${ }^{45 b}$ Later, an improved method was developed using $\mathrm{AlCl}_{3}{ }^{46}$
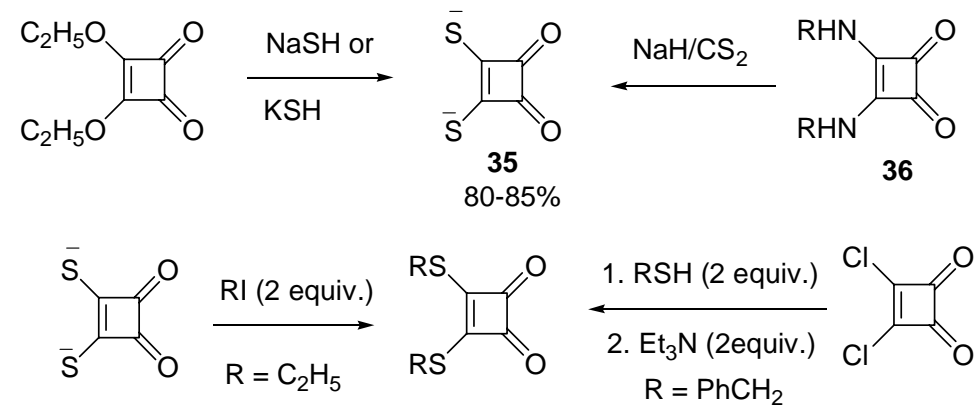

$$
\begin{array}{lll}
\mathrm{R}=\mathrm{C}_{2} \mathrm{H}_{5} & \mathbf{3 7 a} & 91 \% \\
\mathrm{R}=\mathrm{PhCH}_{2} & \mathbf{3 7 b} & 36 \%
\end{array}
$$

\section{Scheme 28}

Similarly, the reaction of 3-chloro-4-phenyl-3-cyclobutene-1,2-dione 29 with pyridine saturated with hydrogen sulfide leads to thioether 38. After acid work up, 3-mercapto-4-phenyl3-cyclobutene-1,2-dione 39a was obtained, which could be converted to thioester 39b with suitable reagents (Scheme 29). ${ }^{2 b, 47 a}$ Similar reactivity was reported between hydrogen selenide and dichloro- or diethoxycyclobutenediones to produce the corresponding selenide derivatives $\mathbf{4 0}$ and 41 (Scheme 30). ${ }^{47 b}$ 


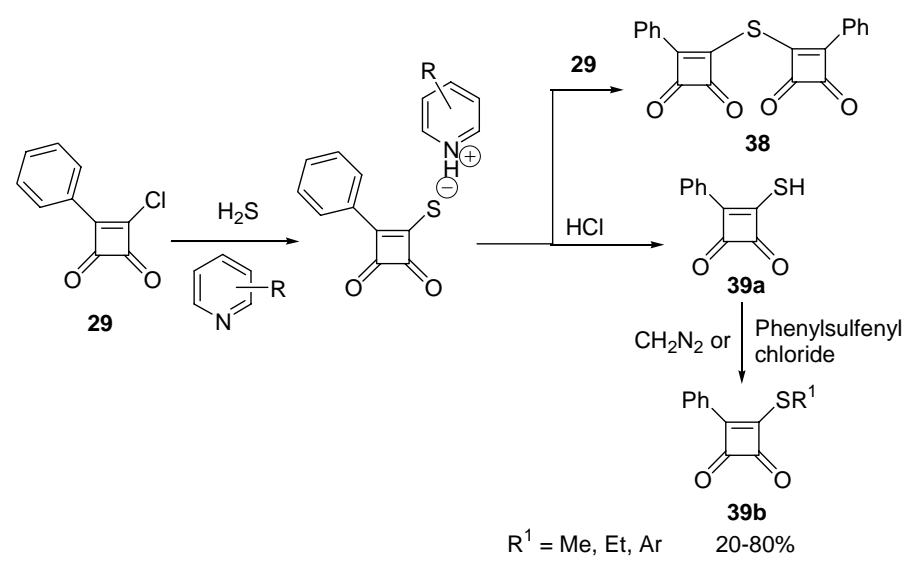

\section{Scheme 29}

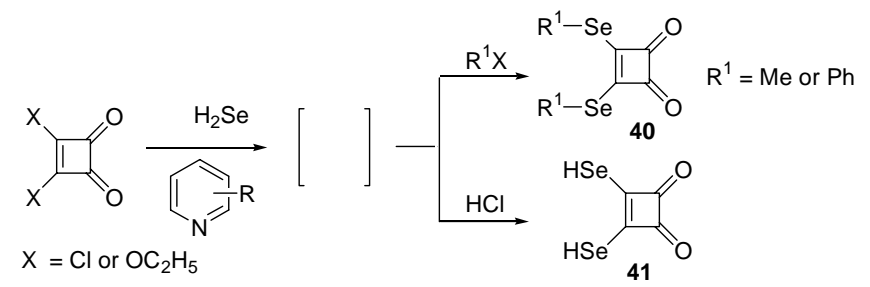

\section{Scheme 30}

\subsection{Amino derivatives of cyclobutenedione}

Amine derivatives of cyclobutenedione are known as amides of squaric acid. Reaction of slight excess of a primary or a secondary amine with dialkylsquarate in $\mathrm{CH}_{3} \mathrm{OH}$ or $\mathrm{CH}_{2} \mathrm{Cl}_{2}$ at room temperature give monoamide monoester $\mathbf{4 2}$ in excellent yield. ${ }^{48,44 a}$ Diamides of squaric acid 36 are prepared under more basic conditions using large excess of amine or by adding triethylamine (Scheme 31). ${ }^{2 \mathrm{~d}}$ Also, halocyclobutenediones react with amines but provide the corresponding amides $\mathbf{4 3}$ in lower yields. ${ }^{49}$
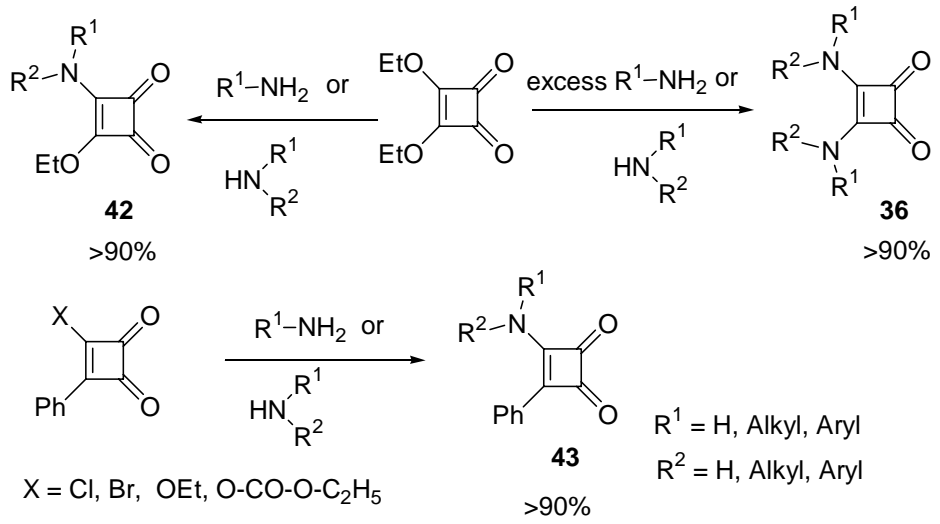

\section{Scheme 31}


This reaction could also be performed in a buffered solution ( $\mathrm{pH} 7)$, which is appropriate for biopolymers. Hence, this controlled nucleophilic substitution forms the basis for the use of diethyl squarate as a coupling reagent to conjugate oligosaccharides to proteins or polyazamacrocycles.$^{50}$ Several biologically active and drug molecules such as 44a-44c have been synthesized following similar methods (Scheme 32). ${ }^{51}$

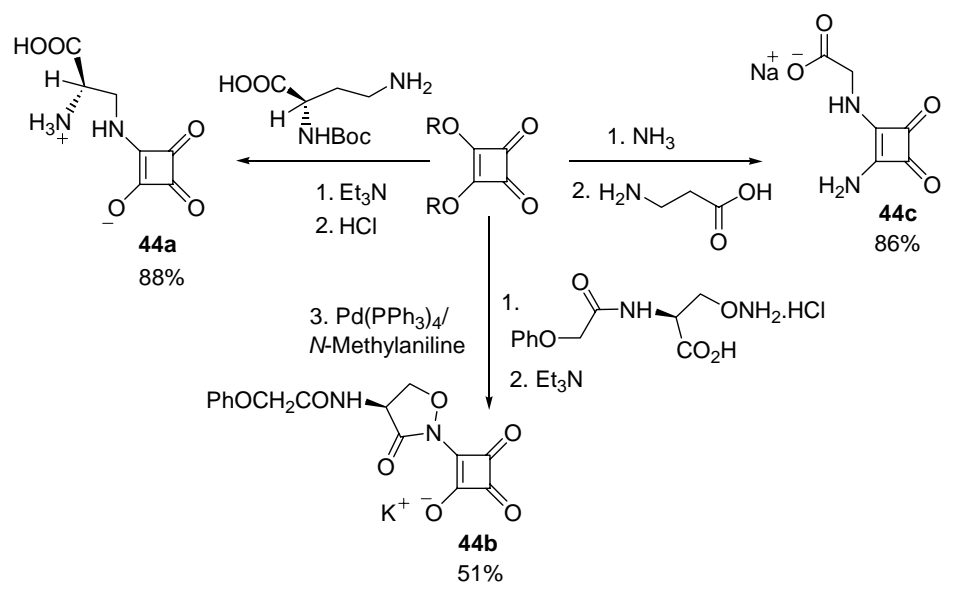

\section{Scheme 32}

Also, it was found that aziridine reacts with dihalocyclobutenedione under suitable conditions to generate either 1,2-diamides 45 or (aziridinoethylamino)cyclobutenedione 46 (Scheme 33). ${ }^{52}$

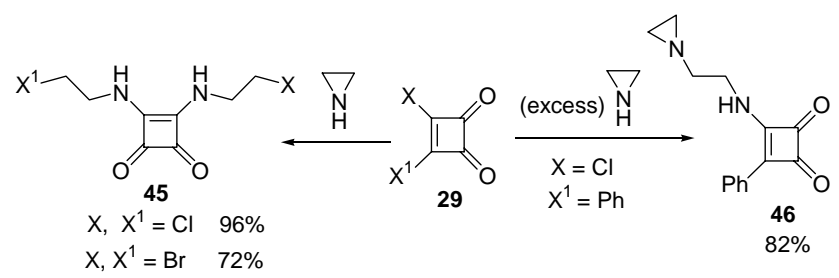

\section{Scheme 33}

Dimethyl squarate reacts with hydrazine and hydroxylamines to form 3,4-dihydrazino-3cyclobutene-1,2-dione $\mathbf{4 7}$ and $N$-hydroxylamide methylesters $\mathbf{4 8}$, respectively (Scheme 34 ). ${ }^{2 \mathrm{~d}, 53}$

\section{Scheme 34}

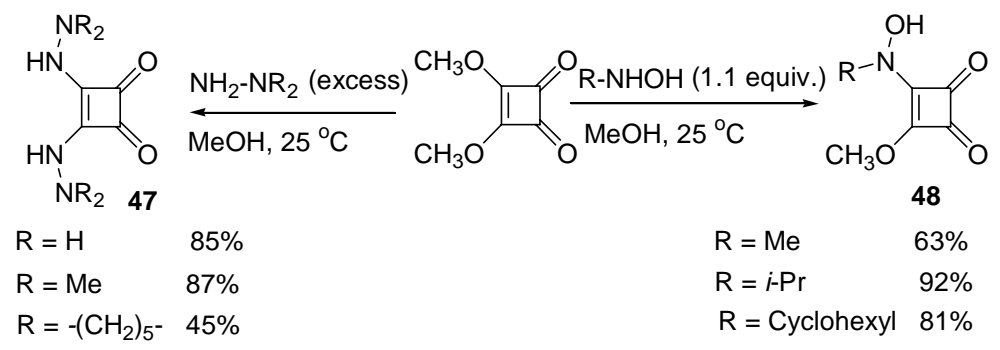


Also, dimethyl squarate undergoes nucleophilic substitution reaction with ortho and paraphenylenediamine to provide 49 and 50, respectively (Scheme 35$)^{2 \mathrm{~d}}$

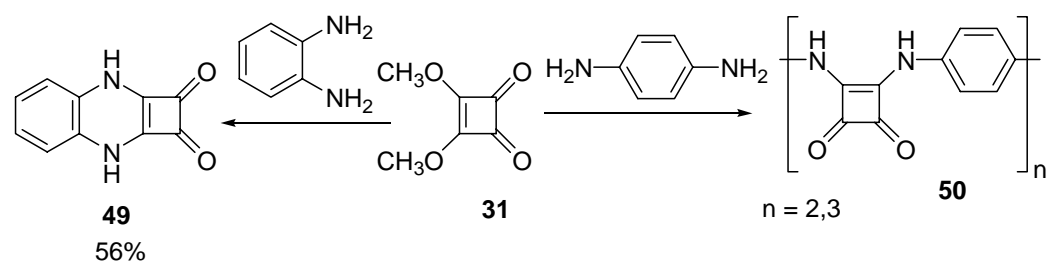

\section{Scheme 35}

Macrocyclic bridged squaric acid diamides of type 51-54 have been ynthesized in good yields by the reaction of 1, $\omega$-diamines with 1,2-dimethoxycyclobutenedione under high dilution conditions (Scheme 36). ${ }^{54}$ Cryptands of type 55 are obtained from 1,2dimethoxycyclobutenedione and monocyclic crown ether amines.

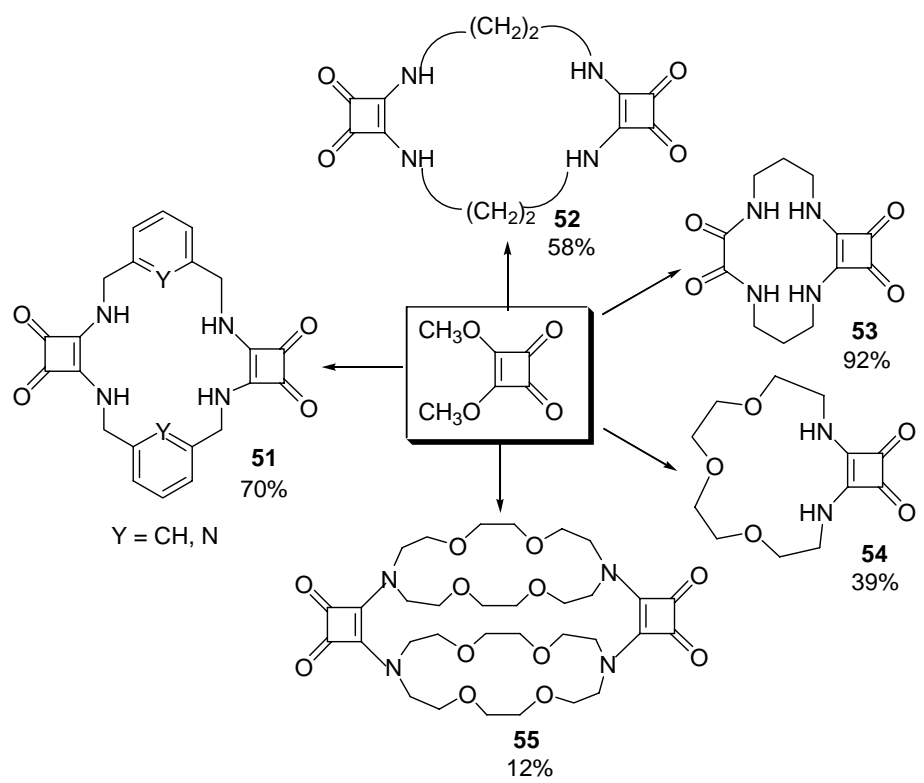

\section{Scheme 36}

Recently, it has been reported that $\mathrm{BF}_{3} \cdot \mathrm{Et}_{2} \mathrm{O}$ or $\mathrm{H}_{2} \mathrm{SO}_{4}$ induces oxidation of some 4hydroxycyclobutenone 56a to furnish the corresponding cyclobutenediones $\mathbf{5 6}$ (Equation 8). ${ }^{55}$
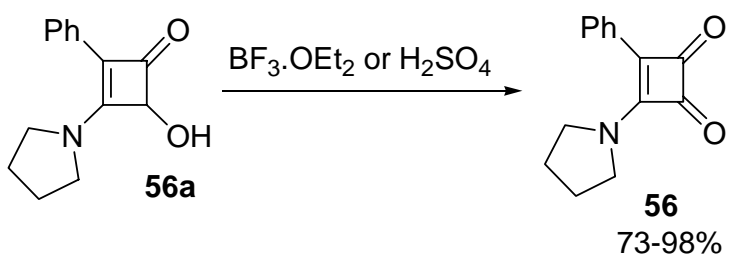


\subsection{Phosphine derivatives of cyclobutenedione}

1,2-Bis(diphenylphosphine)cyclobutenedione $\mathbf{5 8}$ was prepared by the reaction of dichlorocyclobutenedione with diphenyl(trimethylsilyl)phosphine 57 in ether at $-78{ }^{\circ} \mathrm{C}$ (Equation 9). ${ }^{56}$

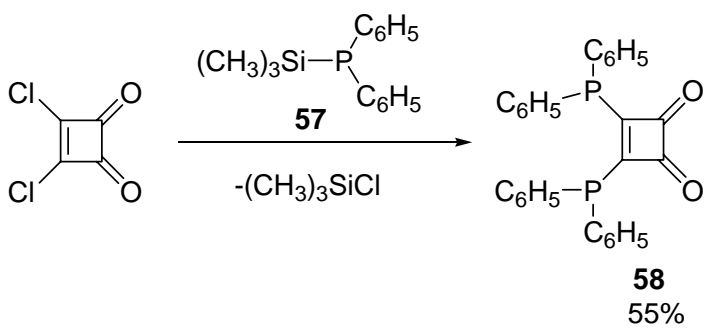

\subsection{Alkyl, alkenyl, alkynyl and aryl derivatives of cyclobutenedione}

Arylcyclobutenediones can be obtained by the reaction of halocyclobutenediones with renas under Friedel-Craft acylation conditions. Dichlorocyclobutenedione 27 affords either mono 29 or diarylcyclobutenediones 9 depending upon the amount of catalyst $\left(\mathrm{AlCl}_{3}\right)$, the molar ratio of reactants and reaction conditions (Scheme 37$).{ }^{57,58}$

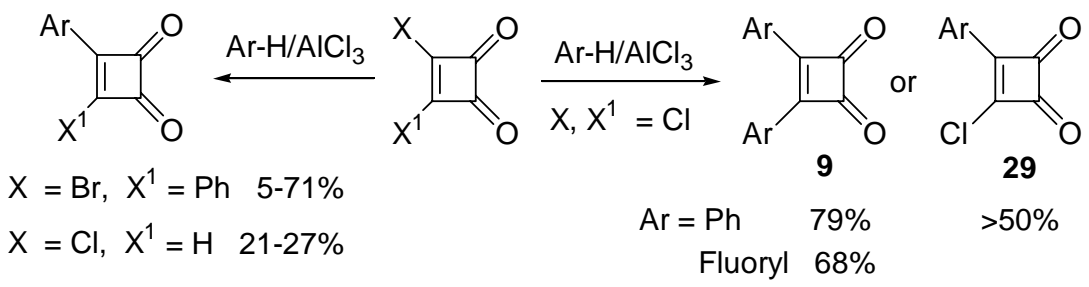

\section{Scheme 37}

A new class of cyclobutenediones containing quinoid rings have been prepared by FriedelCrafts reaction (Scheme 38). Reaction of 1,2-dichloro-3-cyclobutene-1,2-dione with $\mathrm{AlCl}_{3}$ and 2,6-di-t-butylphenol in refluxing dichloromethane yields 59. Compound 59 is readily oxidized to 1,2-diquinocyclobutanedione 60 using $\mathrm{PbO}_{2} .{ }^{59}$

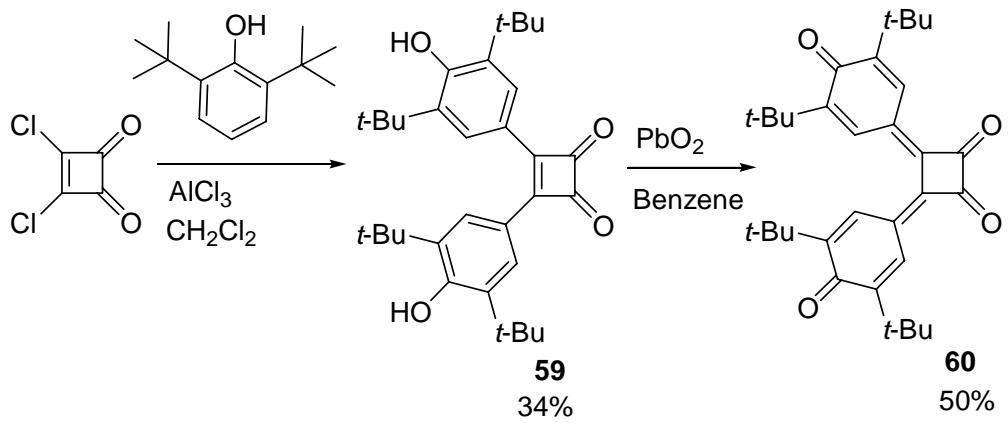

\section{Scheme 38}


3-Amino-4-aryl- and 3-aryl-4-hydroxy-3-cyclobutene-1,2-diones have been obtained by the Meerwein arylation reaction of diazonium salts with squaramides and semisquaric acid, respectively (Equation 10). ${ }^{60}$

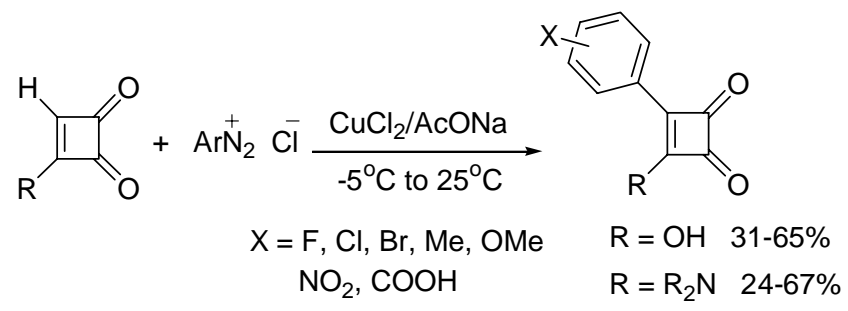

Dichlorocyclobutenedione as well as bromophenylcyclobutenedione 29 condenses with electron rich olefins such as enamines, ketene acetals in the presence of triethylamine (Scheme 39). ${ }^{2 b, 61}$ Similarly, phosphrous and sulphur ylides react with 29 to give the products 61 and 62 with cyclobutenedione moiety acting as a stabilizing acceptor (Scheme 40). ${ }^{62}$

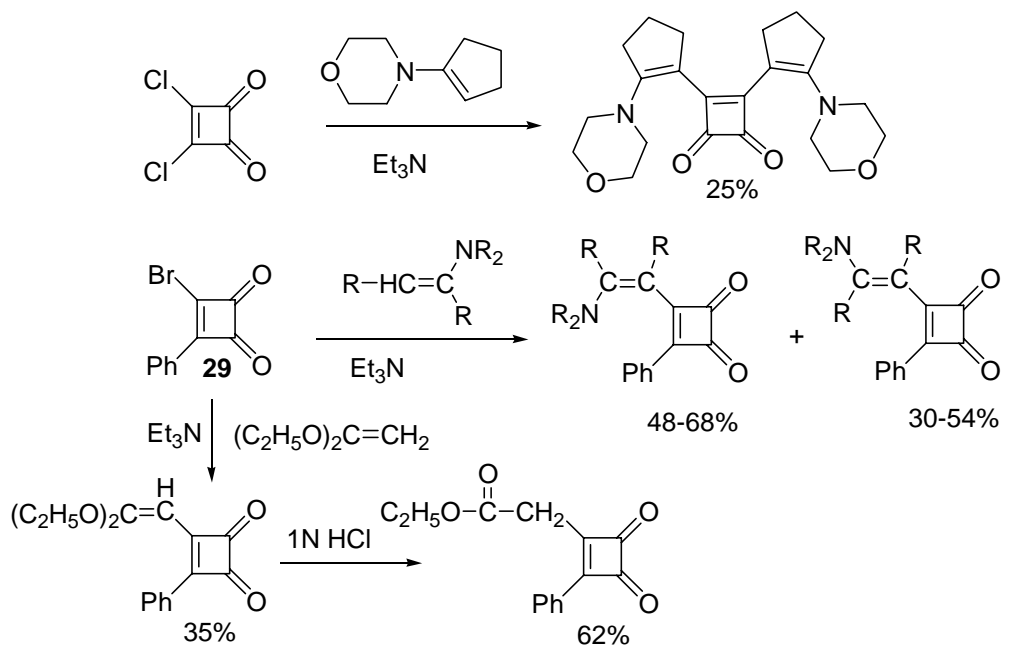

\section{Scheme 39}

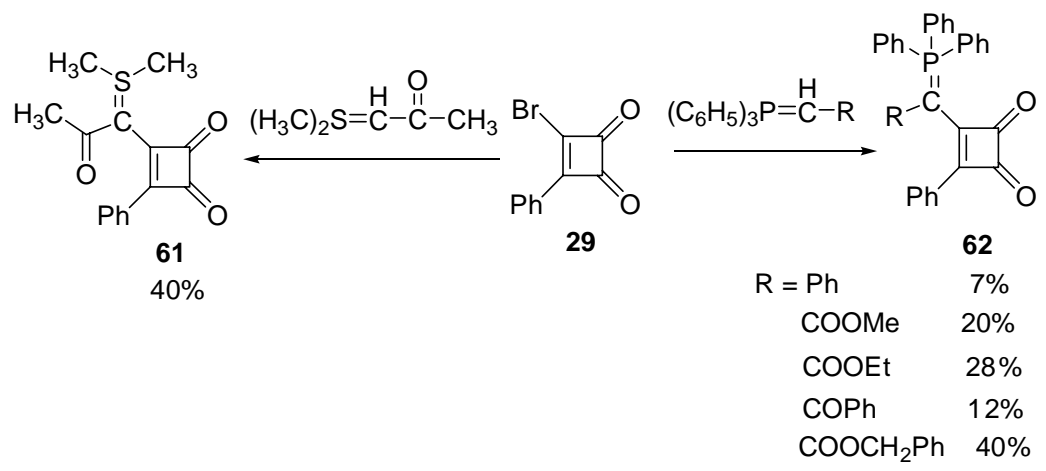

\section{Scheme 40}


Functionalised cyclobutenediones were obtained by the reaction of squarates with compounds having acidic hydrogen on carbon atom in the presence of sodium alkoxide in alcoholic solution. For example, alkoxycyclobutenediones condense smoothly with diethylmalonoate and 1,3-diketones to afford 63 and 64 respectively. ${ }^{63}$ Also, diethylsquarate condenses with 2-methylpyrrole in acetic anhydride to form dipyrrolyl cyclobutenedione 65 (Scheme 41). ${ }^{64}$

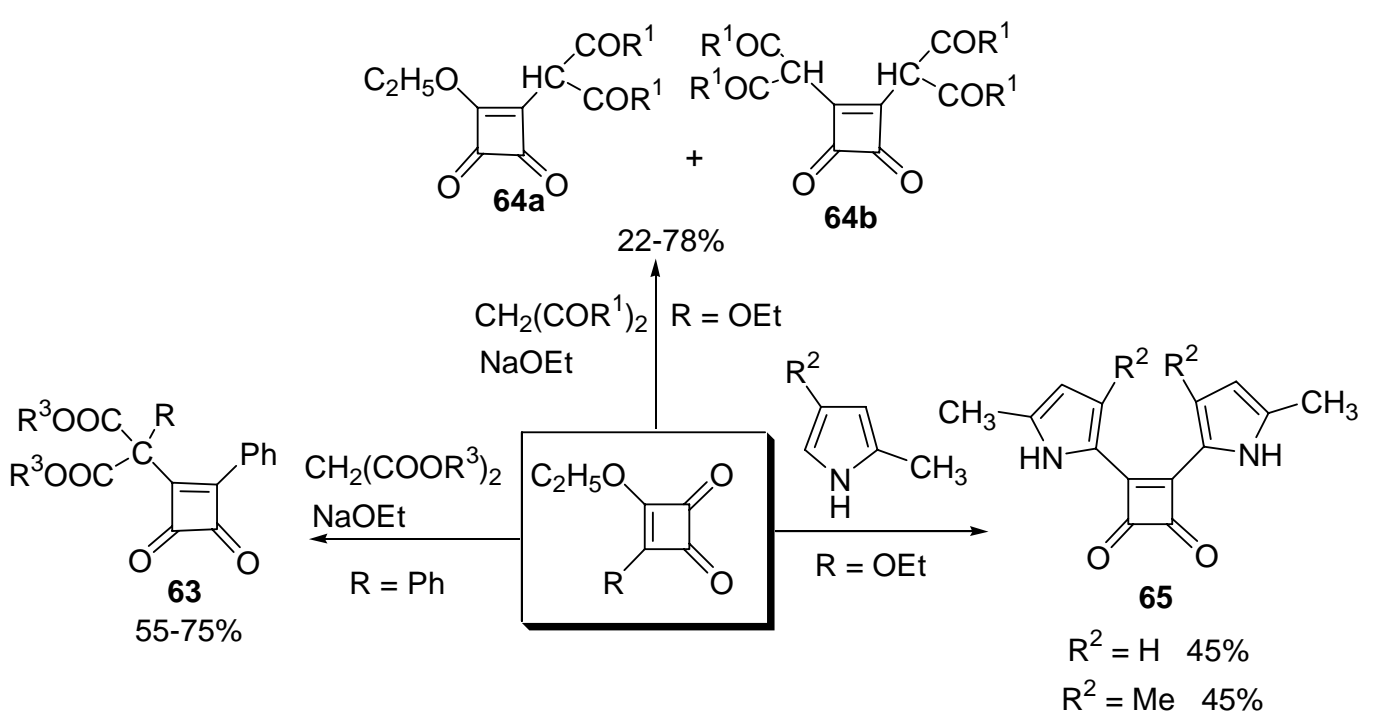

\section{Scheme 41}

Alkyl and alkenyl derivatives of cyclobutenedione have been prepared by the reaction of diazoalkanes with phenylcyclobutenedione through an unusual nucleophilic substitution (Scheme 42). ${ }^{65}$

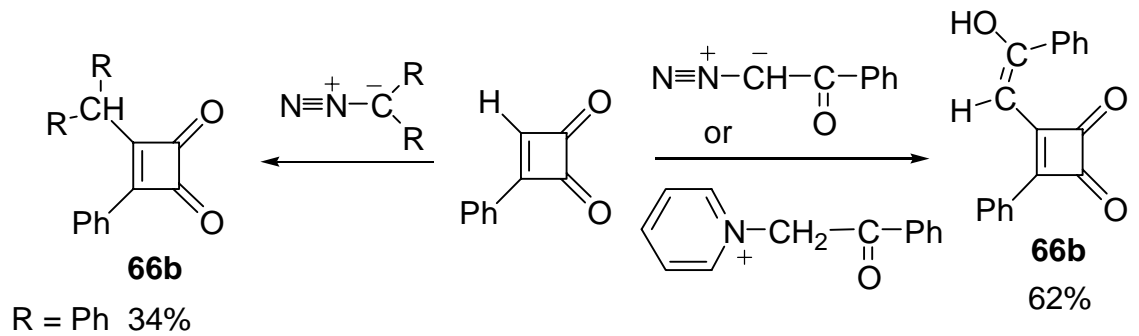

\section{Scheme 42}

3-Ethynyl-4-methoxycyclobutene-1,2-dione 67 was prepared by the addition of vinyllithium to dimethyl squarate followed by quenching of the resulting alkoxide with trifluoroacetic anhydride. Compound $\mathbf{6 7}$ undergoes facile 1,6-addition of carbon and non carbon nucleophiles to form a variety of substituted cyclobutenediones (Scheme 43). ${ }^{66}$ 


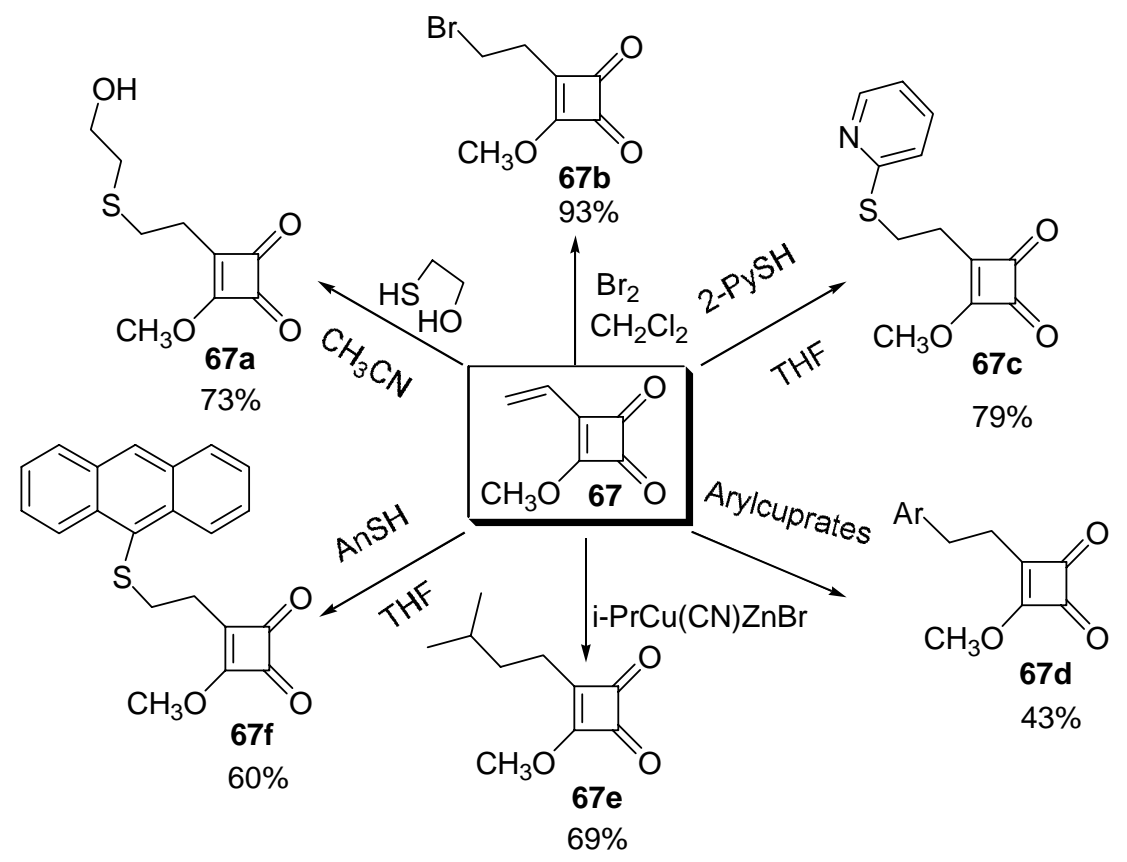

\section{Scheme 43}

A few simple alkyl derivatives of cyclobutenediones are prepared by the reaction of diethylsquarate 32 with Grignard reagents. These reactions proceed in lower yields. ${ }^{67}$ An efficient process was independently developed by Moore ${ }^{68}$ and Liebeskind ${ }^{69}$ via nucleophilic 1,2 addition of organolithium to dialkoxycyclobutenediones followed by hydrolysis of the resulting hydroxycyclobutenone 68 (Scheme 44). Also, differentially disubstituted cyclobutenediones 5 obtained through step-wise addition of two different alkyllithium reagents (Scheme 44, Path b). ${ }^{69}$

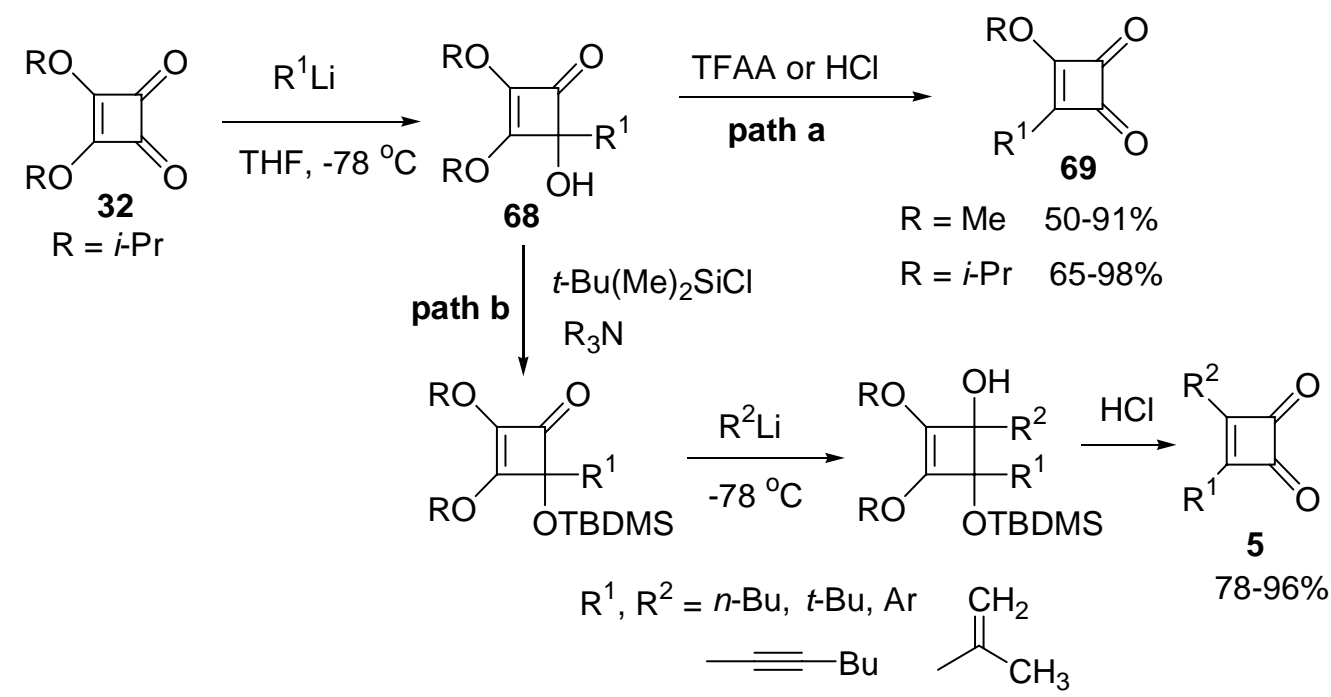

\section{Scheme 44}


These methods, which rely on the introduction of substituents on to cyclobutenedione core as organolithium nucleophiles, are restricted to substituents that are compatible with strongly basic and nucleophilic conditions. Liebeskind et al. ${ }^{70}$ developed a general method involving stable 3(tri-n-butylstannyl)-3-cyclobutene-1,2-dione 70 which was readily prepared by the treatment of 3,4-diisopropoxy-3-cyclobutene-1,2-dione with $n-\mathrm{Bu}_{3} \mathrm{SnSiMe}_{3}$ in the presence of catalytic amount of cyanide ion (Equation 11).

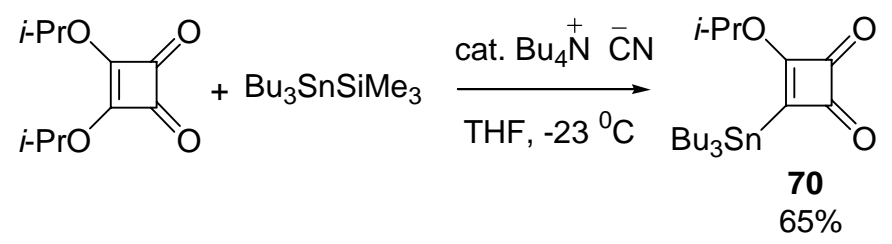

Stannylcyclobutenedione $\mathbf{7 0}$ undergoes cross-coupling with organic iodides attached to $\mathrm{sp}^{3}$, $\mathrm{sp}^{2}$ and sp-hybridised carbon atoms and with vinyl trifluoromethanesulfonate esters in the presence of $\mathrm{PhCH}_{2} \mathrm{ClPd}\left(\mathrm{PPh}_{3}\right)_{2} / \mathrm{CuI}$ catalyst to provide a wide variety of substituted cyclobutenediones $^{51 \mathrm{~b}, 71}$ including porphyrin derivatives 73 (Scheme 45$){ }^{72}$

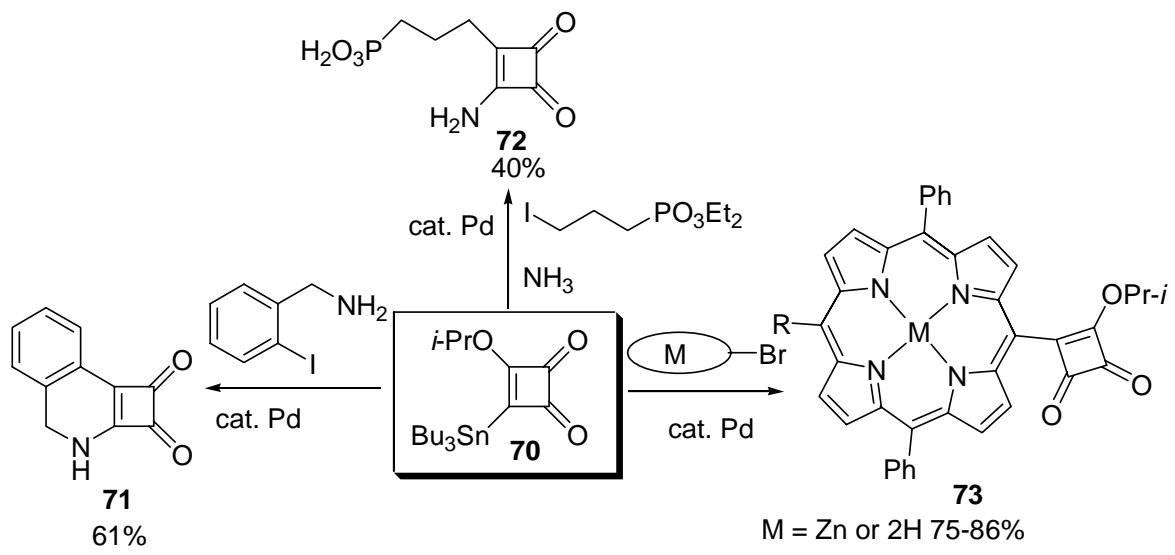

\section{Scheme 45}

Also, a variety of acyl substituted cyclobutenediones were prepared following a similar strategy (Equation 12). ${ }^{71 \mathrm{~b}}$

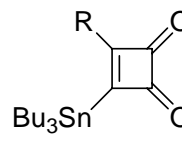

$\frac{\mathrm{R}^{1} \mathrm{COCl}}{\left(\mathrm{Ph}_{3} \mathrm{P}\right)_{2} \mathrm{PdCl}_{2} / \mathrm{Cul}}$

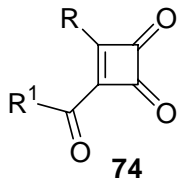

$$
\begin{array}{crcc} 
& \mathrm{R}^{1}=\mathrm{Ph} & (\mathrm{E}) \text {-propenyl } & p-\mathrm{OMeC}_{6} \mathrm{H}_{4} \\
\mathrm{R}=\mathrm{NH}_{2} & 84 \% & 93 \% & 98 \% \\
\mathrm{O} i-\mathrm{Pr} & 79 \% & 68 \% & 65 \% \\
\mathrm{~N} \text {-piperidinyl } & 92 \% & 83 \% & 67 \% \\
\mathrm{~N} \text {-morpholinyl } & 73 \% & &
\end{array}
$$


Bisquaryls, a novel class of compounds derived from squaric acid, have been prepared (Equation 13). ${ }^{71 \mathrm{c}}$<smiles>[R]c1c([SnH3])c(=O)c1=O</smiles>

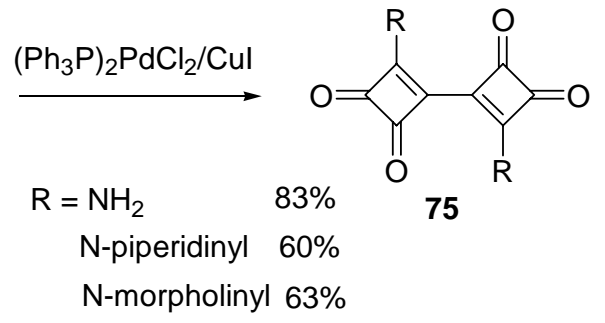

Also, a reverse reaction of above methods has been reported in which cyclobutenediones act as halide partner of Stille cross-coupling, to give a broad array of substituted cyclobutenediones (Equation 14). ${ }^{73}$

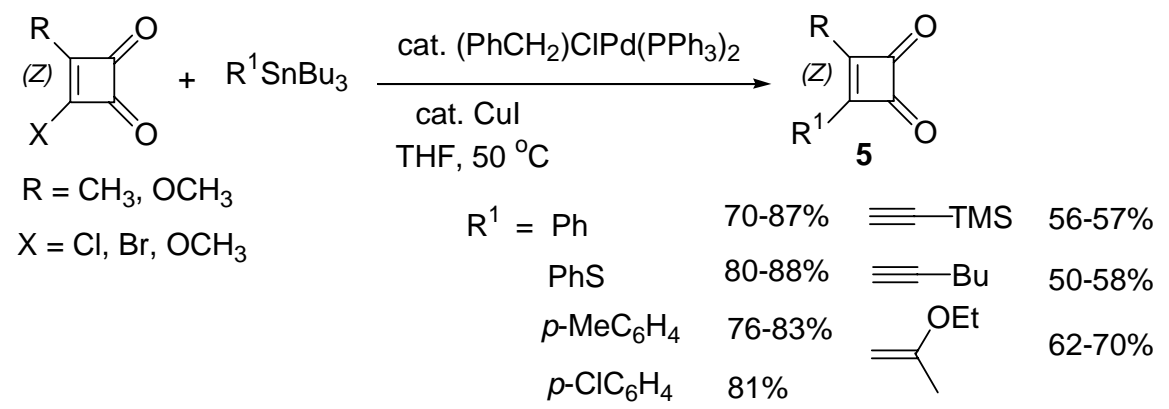

3,4-Dialkynyl-3-cyclobutene-1,2-diones 76 were synthesized by the reaction of 3,4-dichloro3-cyclobutene-1,2-dione either with tri(n-butylstanyl)alkynes in the presence of catalytic amounts of $\mathrm{Pd}\left(\mathrm{PPh}_{3}\right)_{4}$ or with the soluble copper (I) acetylides (Scheme 46). ${ }^{74}$

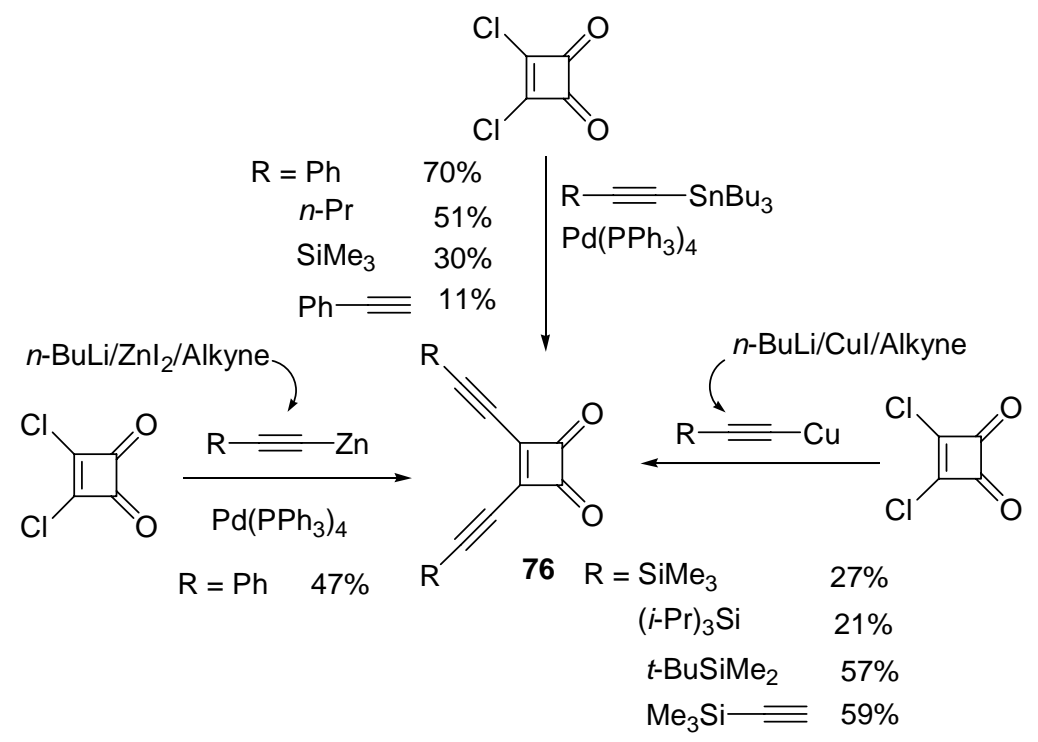

\section{Scheme 46}


Analogous method for the preparation of highly functionalized cyclobutenediones was developed by Knochel et al. ${ }^{75}$ based on zinc-copper reagents (Scheme 47).

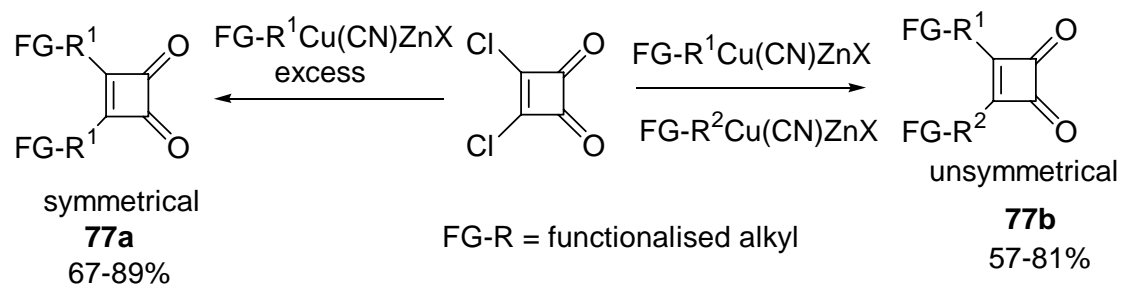

\section{Scheme 47}

\section{Synthesis of benzocyclobutenediones}

As discussed in section 1.2.7, some benzocyclobutenediones were prepared via Diels-Alder addition reactions of some dienes with olefins. Benzocyclobutenediones were also synthesized starting from certain aromatic compounds. Benzocyclobutenedione $\mathbf{7 8}$ was first synthesized by Cava et al. ${ }^{76}$ using simple organic transformations from 1,2-diiodobenzocyclobutene as shown in Scheme 48.

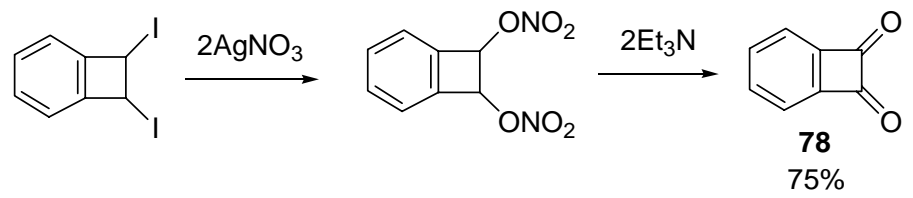

\section{Scheme 48}

Bromination of 3,8-diphenylnaphtho[b]cyclobutene $\mathbf{7 9}$ with NBS generates tetrabromoderivative $\mathbf{8 0}$ along with a mixture of other bromides. The tetrabromide $\mathbf{8 0}$ reacts with silver trifluoroacetate and water to give 3,8-diphenylnaphtho[b]cyclobutene-1,2-dione 81 (Scheme 49). ${ }^{77}$

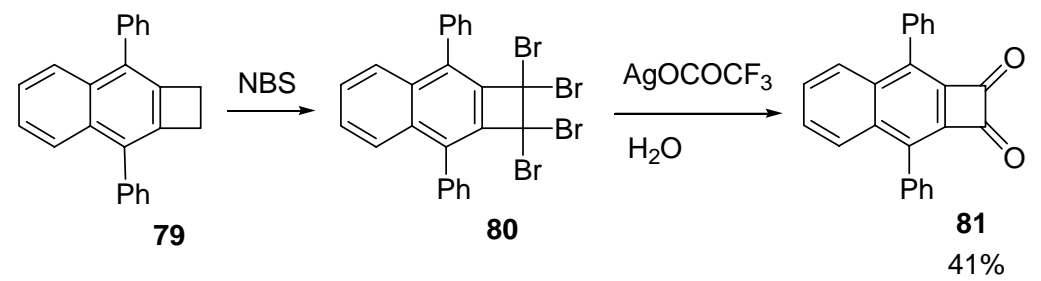

\section{Scheme 49}

Also, 3-aminobenzocyclobutenedione $\mathbf{8 3}$ has been prepared via the oxidation of luminol 82 using $t$-butyl hypochlorite (Scheme 50). ${ }^{78}$ 


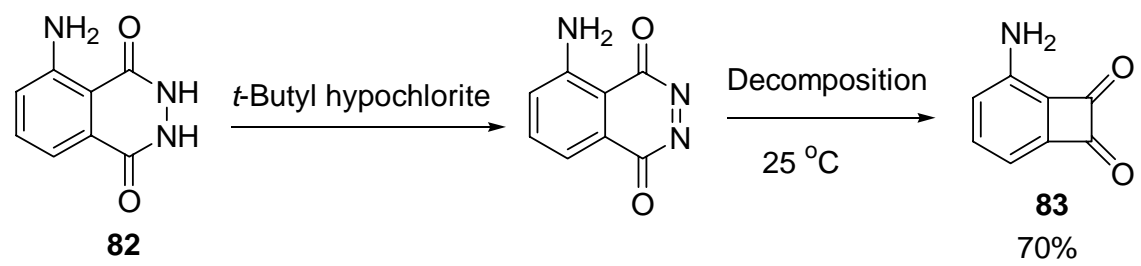

\section{Scheme 50}

It has been reported that the vapour phase pyrolysis of indanetrione $84^{79 a}$ and 3bezyloxyphthalide $\mathbf{8 5}^{79 \mathrm{~b}}$ give traces of benzocyclobutenedione $\mathbf{7 8}$, whereas phthalamidodiphenylsulphoxide $\mathbf{8 6}$ gives benzocyclobutenedione in 35-70\% yield under similar conditions (Scheme 51). ${ }^{79 \mathrm{c}}$

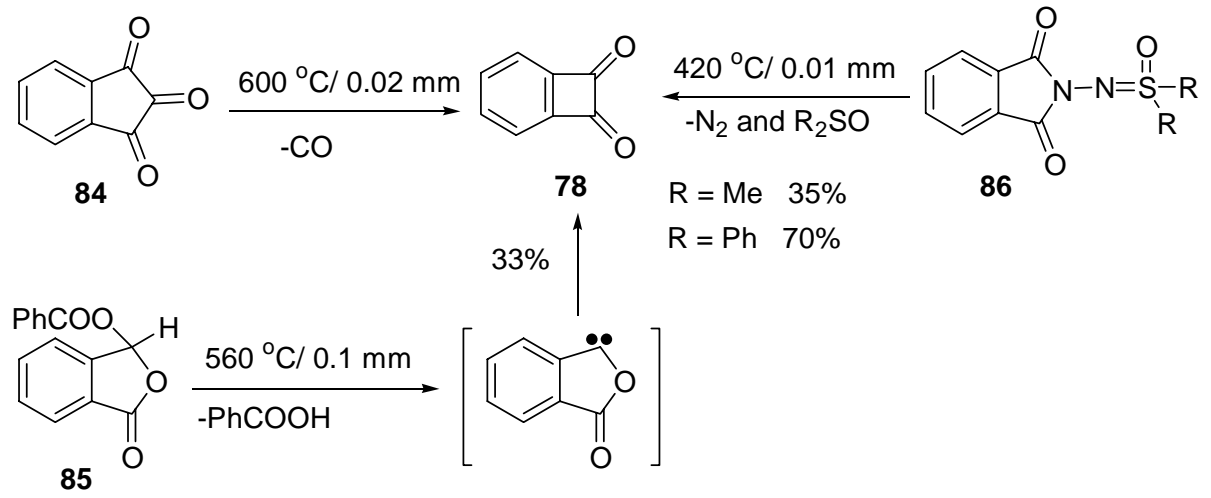

\section{Scheme 51}

Synthesis of benzocyclobutenediones, on multi-gram scale, was achieved by flash vacuum pyrolysis of the Diels-Alder adducts of phthalazine-1,4-diones 87 with anthracene, cyclopentadiene $^{80}$ or indene ${ }^{80}$ (Scheme 52). Among these, the anthracene adduct 88 a gave better yields. $^{81}$

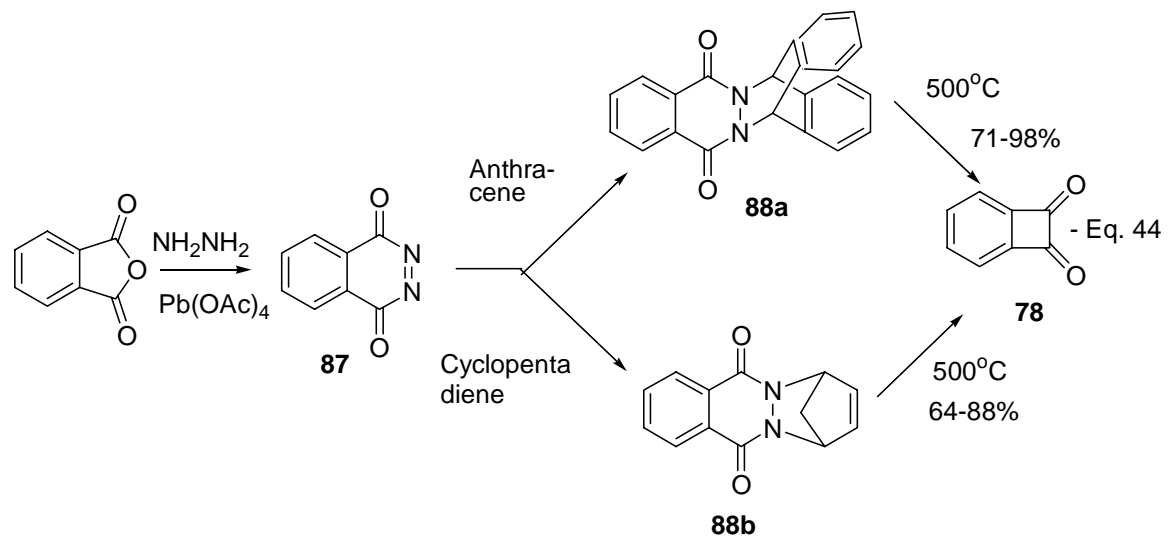

Scheme 52 


\section{Conclusions}

In view of applications of cyclobutenediones as versatile starting materials in the synthesis of multifunctional carbocyclic and heterocyclic compounds, biologically active molecules and NLO materials, the methods of synthesis of these important class of compounds should be helpful in further development in these areas.

\section{Acknowledgements}

We are thankful to the CSIR (New Delhi) for support. We are also grateful to the UGC (New Delhi) for support under "University of Potential for Excellence" Program.

\section{References}

1. (a) Smutny, E. J.; Roberts, J. D. J. Am. Chem. Soc. 1955, 77, 3420. (b) Smutny, E. J.; Caserio, M. C.; Roberts, J. D. J. Am. Chem. Soc. 1960, 82, 1793. (c) Cava, M. P.; Mitchel, M. J. Cyclobutadiene and Related Compounds; Academic Press: New York, 1967.

2. (a) Schmidt, A. H.; Ried, W. Synthesis 1978, 1. (b) Knorr, H.; Ried, W. Synthesis 1978, 649.

(c) Schmidt, A. H.; Ried, W. Synthesis 1978, 869. (d) Schmidt, A. H. Synthesis 1980, 961.

3. (a) West, R.; Niu, J. Non-Benzenoid Aromatics; Academic Press: New York, 1969, Vol. 1, p 132. (b) West, R.; Niu, H. Y.; Powell, D. L.; Evans, M. V. J. Am. Chem. Soc. 1960, 82, 6204. (c) West, R.; Powell, D. L. J. Am. Chem. Soc. 1963, 85, 2577. (d) Ito, M.; West, R. J. Am. Chem. Soc. 1963, 85, 2580.

4. (a) Cole, R. J.; Kirksey, J. W.; Cutler, H. G.; Doupnik, B. L.; Peckham, J. C. Science 1973, 179, 1324. (b) Sringer, J. P.; Clardy, J.; Cole, R. J.; Kirksey, J. W.; Hill, R. K.; Carlson, R. M.; Isidor, J. J. Am. Chem. Soc. 1974, 96, 2267. (c) Pirrung, M. C.; Nauhaus, S. K.; Sing, B. J. Org. Chem. 1996, 61, 2592.

5. (a) Tietze, L. F.; Arlt, M.; Beller, M.; Glusenkamp, K. H.; Jahde, E.; Rajewsky, M. F. Chem. Ber. 1991, 124, 1215. (b) Gardner, S. H.; Freyschmidt-Paul, P.; Hoffman, R.; Sundberg, J. P.; Happle, R.; Nigel, J.; Tobin, D. J. Eur. J. Dermatol. 2000, 10, 443. (c) Freyschmidt-paul, P.; Sundberg, J. P.; Happle, R.; McElwee, K. J.; Metz, S.; Boggess, D.; Hoffman, R. J. Investigative Dermatol. 1999, 113, 61. (d) Kazumasa, M.; Motonobu, N.; Miyako, N.; Tatsuo, K.; Yoshiki, M. J. Dermatol. 2002, 29, 661. (e) Silverberg, N. B.; Lim, J. K.; Paller, A. S.; Mancini, A. J. J. Am. Acad. Dermatol. 2000, 42, 803.

6. (a) Douglas, K. T.; Nadvi, I. N. FEBS Lett. 1979, 106, 393. (b) Burka, L. T.; Doran, J.; Wilson, B. J. Biochem. Pharmacol. 1982, 31, 79. (c) Xie, J.; Comeau, A. B.; Seto, C. T. Org. Lett. 2004, 6, 83. 
7. (a) Sato, K.; Seio, K.; Sekine, M. J. Am. Chem. Soc. 2002, 124, 12715. (b) Beaulieu, P. L.; Cameron, D. R.; Ferland, J. -M.; Gauthier, J.; Ghiro, E.; Gillard, J.; Gorys; Poirier, M.; Rancourt, J.; Wernic, D.; Llinas-Brunet, M.; Betageri, R.; Cardozo, M.; Hickey, E. R.; Ingraham, R.; Jakes, S.; Kabcenell, A.; Kirrane, T.; Lukas, S.; Patel, U.; Proudfoot, J.; Sharma, R.; Tong, L.; Moss, N. J. Med. Chem. 1999, 42, 1757.

8. Kinney, W. A.; Abou-Gharbia, M.; Garrison, D. T.; Schmidt, J.; Kowal, D. M.; Bramlett, D. R.; Miller, T. L.; Tasse, R. P.; Zaleska, M. M.; Moyer, J. A. J. Med. Chem. 1998, 41, 236.

9. Chan, P. C. M.; Roon, R. J.; Koerner, J. F.; Taylor, N. J.; Honek, J. F. J. Med. Chem. 1995, $38,4433$.

10. (a) Tomas, S.; Rotger, M. C.; Gonzalez, J. F.; Deya, P. M.; Ballester, P.; Costa, A. Tetrahedron Lett. 1995, 36, 2523. (b) Tomas, S.; Prohens, R.; Deslongchamps, G.; Ballester, P.; Costa, A. Angew. Chem., Int. Ed. 1999, 38, 2208. (c) Prohens, R.; Martorell, G.; Ballester, P.; Costa, A. Chem. Commun. 2001, 1456.

11. (a) Liebeskind, L. S. Tetrahedron 1989, 45, 3053. (b) Liebeskind, L. S.; Mitchell, D.; Foster, B. S. J. Am. Chem. Soc. 1987, 109, 7908. (c) Liebeskind, L. S.; Bombrun, A. J. Org. Chem. 1994, 59, 1149. (d) Sun, L.; Liebeskind, L. S. J. Org. Chem. 1994, 59, 6856. (e) Sun, L.; Liebeskind, L. S. J. Am. Chem. Soc. 1996, 118, 12473. (f) Mingo, P.; Zhang, S.; Liebeskind, L. S. J. Org. Chem. 1999, 64, 2145. (g) Zhang, S.; Liebeskind, L. S. J. Org. Chem. 1999, 64, 4042.

12. (a) Perri, S. T.; Rice, P.; Moore, H. W. Org. Synth. 1990, 69, 220. (b) Moore, H. W.; Yerxa, B. R. Adv. Strain Org. Chem. 1995, 4, 81. (c) Foland, L. D.; Karlsson, J. O.; Perri, S. T.; Schwabe, R.; Xu, S. L.; Patil, S.; Moore, H. W. J. Am. Chem. Soc. 1989, 111, 975. (d) Karlsson, J. O.; Nguyen, N. V.; Foland, L. D.; Moore, H. W. J. Am. Chem. Soc. 1985, 107, 3392. (e) Xu, S. L.; Xia, H.; Moore, H. W. J. Org. Chem. 1991, 56, 6094. (f) Lee, K. H.; Moore, H. W. J. Org. Chem. 1995, 60, 735. (g) Taing, M.; Moore, H. W. J. Org. Chem. 1996, 61, 329. (h) Tiedemann, R.; Turnbull, P.; Moore, H. W. J. Org. Chem. 1999, 64, 4030.

13. (a) Negri, J. T.; Morwick, T.; Doyon, J.; Wilson, P. D.; Hickey, E. R.; Paquette, L. A. J. Am. Chem. Soc. 1993, 115, 12189. (b) Paquette, L. A.; Morwick, T. M.; Negri, J. T.; Rogers, R. D. Tetrahedron 1996, 52, 3075. (c) Paquette, L. A.; Morwick, T. M. J. Am. Chem. Soc. 1997, 119, 1230. (d) Paquette, L. A.; Kuo, L. H.; Tae, J. J. Org. Chem. 1998, 63, 2010. (e) Geng, F.; Liu, J.; Paquette, L. A. Org. Lett. 2002, 4, 71.

14. (a) Zora, M.; Herndon, J. W. Organometallics 1993, 12, 248. (b) Kondo, T.; Nakamura, A.; Okada, T.; Suzuki, N.; Wada, K.; Mitsudo, T.-a. J. Am. Chem. Soc. 2000, 122, 6319. (c) Nair, V.; Sheela, K. C.; Rath, N. P.; Eigendorf, G. K. Tetrahedron Lett. 2000, 41, 6217. (d) Allen, A. D.; Ma, J.; McAllister, M. A.; Tidwell, T. T.; Zhao, D.-c. Acc. Chem. Res. 1995, $28,265$.

15. Zhang, J.; Zhou, H. -B.; Lü, S.-M.; Luo, M.-M.; Xie, R. G.; Choi, M. C. K.; Zhou, Z.-Y.; Chan, S. C.; Yang, T.-K. Tetrahedron: Asymmetry 2001, 12, 1907. 
16. (a) Ashwell, G. J.; Jefferies, G.; Hamilton, D. G.; Lynch, D. E.; Roberts, M. P. S.; Bahra, G.

S.; Brown, C. R. Nature 1995, 375, 385. (b) Pu, L. S. Chem. Commun. 1991, 429. (c) Law, K. Y.; Bailey, F. C. J. Org. Chem. 1992, 57, 3278.

17. Law, K. -Y.; Bailey, F. C. Chem. Commun. 1990, 863.

18. (a) Ried, W.; Schmidt, A. H. Angew. Chem., Int. Ed. 1972, 11, 997. (b) Ried, W.; Schmidt, A. H.; Saxena, V. B. Chem. Ber. 1970, 103, 2709. (c) Ried, W.; Schmidt, A. H.; Kuhn, W. Chem. Ber. 1971, 104, 2622.

19. (a) Hinshaw, J. C. Chem. Commun. 1971, 630. (b) Scharf, H.-D.; Seidler, H. Chem. Ber. 1971, 104, 2995.

20. (a) Dehmlow, E. V. Chem. Ber. 1967, 100, 3829. (b) Knoche, H. Liebigs Ann. 1969, 722, 232.

21. Bou, A.; Pericas, M. A.; Serratosa, F. Tetrahedron Lett. 1982, 23, 361.

22. Ooms, P. H.; Scheeren, J. W.; Nivard, R. J. F. Synthesis 1975, 639.

23. (a) Bellus, D. J. Am. Chem. Soc. 1978, 100, 8026. (b) Brady, W. T.; Watts, R. D. J. Org. Chem. 1980, 45, 3525. (c) Bellus, D. J. Org. Chem. 1979, 44, 1208. (d) Brady, W. T.; Saidi, K. J. Org. Chem. 1980, 45, 727. (e) Hoffmann, R. W.; Bressel, U.; Gehlhaus, J.; Hauser, H. Chem. Ber. 1971, 104, 873. (f) Fetizon, M.; Hanna, I. Synthesis 1990, 583.

24. Liebeskind, L. S.; Baysdon, S. L. Tetrahedron Lett. 1984, 25, 1747.

25. (a) Park, J. D.; Cohen, S.; Lacher, J. R. J. Am. Chem. Soc. 1959, 81, 3480. (b) Park, J. D.; Cohen, S.; Lacher, J. R. J. Am. Chem. Soc. 1962, 84, 2919. (c) Blomquist, A. T.; Verling, R. Tetrahedron Lett. 1961, 655. (d) Blomquist, A. T.; LaLancette, E. A. J. Am. Chem. Soc. 1961, 83, 1387. (e) Ried, W.; Lantzsch, R. Chem. Ber. 1971, 104, 679.

26. (a) Scharf, H.-D. Angew. Chem., Int. Ed. 1974, 13, 520. (b) Hinshaw, J.C. Chem. Commun. 1971,630.

27. (a) Toda, F.; Ishihara, H.; Akagi, K. Tetrahedron Lett. 1969, 2531. (b) Toda, F.; Akagi, K. Chem. Commun. 1970, 764.

28. South, M. S.; Liebeskind, L. S. J. Org. Chem. 1982, 47, 3815.

29. Schmidt, A. H.; Kunz, C. Synthesis 1991, 78.

30. Roedig, A.; Bonse, G.; Helm, R.; Kohlhaupt, R. Chem. Ber. 1971, 104, 3378.

31. Camps, F.; Llebaria, A.; Moreto, J. M.; Ricart, S.; Vinas, J. M. Tetrahedron Lett. 1990, 31, 2479.

32. Suzuki, Y.; Takizawa, T. Chem. Commun. 1972, 837.

33. LePage, T.; Nakasuji, K.; Breslow, R. Tetrahedron Lett. 1985, $26,5919$.

34. Whiting, M. C. Chem. Weekblad 1963, 53, 119.

35. (a) Hoberg, H.; Herrera, A. Angew. Chem., Int. Ed. 1980, 19, 927. (b) Hoberg, H.; Herrera, A. Angew. Chem., Int. Ed. 1981, 20, 876.

36. (a) Periasamy, M.; Radhakrinhnan, U.; Brunet, J. J.; Chauvin, R.; El zaizi, A. Chem. Commun. 1996, 1499. (b) Periasamy, M.; Rameshkumar, C.; Radhakrinhnan, U.; Brunet, J. J. J. Org. Chem. 1998, 63, 4930.

37. Periasamy, M.; Rameshkumar, C.; Radhakrinhnan, U. Tetrahedron Lett. 1997, 38, 7229. 
38. Rameshkumar, C.; Periasamy, M. Organometallics 2000, 19, 2400.

39. (a) Rameshkumar, C.; Periasamy, M. Tetrahedron Lett. 2000, 41, 2719. (b) Periasamy, M.; Mukkanti, A.; ShyamRaj, D. Organometallics 2004, 23, 619.

40. Breslow, R.; Altman, L. J.; Krebs, A.; Mohacsi, E.; Murata, I.; Peterson, R. A.; Posner, J. J. Am. Chem. Soc. 1965, 87, 1326.

41. (a) DeBoer, C. D. Chem. Commun. 1972, 377. (b) Komendankov, M. I.; Domnin, I. M.; Kenbaeva, R. M.; Grigorova, T. N. Zh. Org. Khim. 1973, 9, 142.

42. (a) Obata, N.; Takizawa, T. Tetrahedron Lett. 1970, 2231. (b) Chickos, J. S. J. Org. Chem. 1973, 38, 3642.

43. De Selms, R. C.; Fox, C. J.; Riordan, R. C. Tetrahedron Lett. 1970, 781.

44. (a) Cohen, S.; Cohen, S. G. J. Am. Chem. Soc. 1966, 88, 1533. (b) Schmidt, A. H.; Jacob, K. Liebigs Ann. 1970, 742, 116. (c) Treibs, A.; Ried, W. Liebigs Ann. 1966, 699, 153.

45. (a) Coucouvanis, D.; Hollander, F. J.; West, R.; Eggerding, D. J. Am. Chem. Soc. 1974, 96, 3006. (b) Eggerding, D.; West, R. J. Org. Chem. 1976, 41, 3904.

46. Schmidt, A. H.; Kunz, C.; Debo, M.; Mora-Ferrer, J.-P. Synthesis 1990, 819.

47. (a) Schmidt, A. H.; Ried, W.; Pustolemsek, P.; Dietschmann, H. Angew. Chem., Int. Ed. 1972, 11, 142. (b) Schmidt, A. H.; Ried, W.; Pustoslemsek, P. Chem. Ztg. 1977, 101, 154.

48. (a) Maahs, G.; Hegenberg, P. Angew. Chem., Int. Ed. 1966, 5, 888. (b) P. Cohen, S.; Cohen, S. G. J. Am. Chem. Soc. 1966, 88, 1533. (c) Thrope, J. E. J. Chem. Soc. (B) 1968, 435. (d) Neuse, E.; Green, B. Liebigs Ann. 1973, 619.

49. Ried, W.; Kunstmann, W. Chem. Ber. 1969, 102, 1431.

50. (a) Vermeer, H. J.; Halkes, K. M.; van Kuik, A.; Kamerling, J. P.; Vliegenthart, J. F. G. J. Chem. Soc., Perkin Trans. 1 2000, 2249. (b) Corsi, D. M.; Elst, L. V.; Muller, R. N.; van Bekkum, H.; Peters, J. A. Chem. Eur. J. 2001, 7, 64. (c) Kitov, P. I.; Bundle, D. R. J. Chem. Soc., Perkin Trans. 1 2001, 838. (d) Chernyak, A.; Karavanov, A.; Ogawa, Y.; Kovac, P. Carbohydr. Res. 2001, 330, 479.

51. (a) Ueda, Y.; Crast, L. B.; Jr.; Mikilineni, A. B.; Partyka, R. A. Tetrahedron Lett. 1991, 32, 3767. (b) Kinney, W. A. Tetrahedron Lett. 1993, 34, 2715.

52. (a) Schmidt, A. H.; Ried, W. Liebigs Ann. 1975, 1863. (b) Ried, W.; Schmidt, A. H. Tetrahedron Lett. 1969, 2435. (c) Ried, W.; Schmidt, A. H. Tetrahedron Lett. 1969, 3007. (d) Ried, W.; Schmidt, A. H. Tetrahedron Lett. 1969, 4115.

53. Lim, N. C.; Morton, M. D.; Jenkins, H. A; Bruckner, C. J. Org. Chem. 2003, 68, 9233.

54. Vogtle, F.; Dix, P. Liebigs Ann. 1977, 1698.

55. Wang, J.; Jiang, X.; Chen, M.; Ge, Z.; Hu, Y.; Hu, H. J. Chem. Soc., Perkin Trans. 1 2001, 66.

56. Becher, H. J.; Fenske, D.; Langer, E. Chem. Ber. 1973, 106, 177.

57. Schmidt, A. H.; Kircher, G.; Maus, S.; Bach, H. J. Org. Chem. 1996, 61, 2085 and the references cited there in.

58. (a) Green, B. R.; Neuse, E. W. Synthesis 1974, 46. (b) Green, B. R.; Neuse, E. W. J. Org. Chem. 1974, 39, 1585. 
59. Wendling, L. A.; Koster, S. K.; Murray, J. E.; West, R. J. Org. Chem. 1977, 42, 1126.

60. Schmidt, A. H.; Schmitt, G.; Diedrich, H. Synthesis 1990, 579.

61. Ried, W.; Batz, F. Liebigs Ann. 1972, 755, 32.

62. (a) Ried, W.; Medem, H. Chem. Ber. 1975, 108, 554. (b) Knorr, U.; Knorr, H.; Ried, W.; Scheckmann, W. Chem. Ber. 1976, 109, 3869.

63. (a) Roth, H. J.; Sporlender, H. Tetrahedron Lett. 1968, 6223. (b) Roth, H. J.; Sporlender, H. Arch. Pharmaz. 1970, 303, 886. (c) Sporlender, H.; Roth, H. J. Arch. Pharmaz. 1972, 305, 239.

64. Treibs, A.; Jacob, K. Liebigs Ann. 1966, 699, 153.

65. Ried, W.; Schmidt, A. H.; Kuhn, W.; Bierendemfel, A. Tetrahedron Lett. 1972, 3885.

66. Xu, S.; Yerxa, B. R.; Sullivan, R. W.; Moore, H. W. Tetrahedron Lett. 1991, 32, 1129.

67. Kraus, J. L. Tetrahedron Lett. 1985, 26, 1867.

68. Reed, M. W.; Pollart, D. J.; Perri, S. T.; Foland, L. D.; Moore, H. W. J. Org. Chem. 1988, 53, 2477.

69. Liebeskind, L. S.; Fengl, R. W.; Wirtz, K. R.; Shawe, T. T. J. Org. Chem. 1988, 53, 2482.

70. Liebeskind, L. S.; Fengl, R. W. J. Org. Chem. 1990, 55, 5359.

71. (a) Liebeskind, L. S.; Zhang, J. J. Org. Chem. 1991, 56, 6379. (b) Liebeskind, L. S.; Yu, M.

S.; Fengl, R. W. J. Org. Chem. 1993, 58, 3543. (c) Liebeskind, L. S.; Yu, M. S.; Yu, R. H.; Wang, J.; Hagen, K. S. J. Am. Chem. Soc. 1993, 115, 9048.

72. Shi, X.; Amin, Sk. R.; Liebeskind, L. S. J. Org. Chem. 2000, 65, 1650.

73. Liebeskind, L. S.; Wang, J. Tetrahedron Lett. 1990, 31, 4293.

74. (a) Rubin, Y.; Sophia, S. L.; Knobler, C. B.; Anthony, J.; Boldi, A. M.; Diederich, F. J. Am. Chem. Soc. 1991, 113, 6943. (b) Rubin, Y.; Knobler, C. B.; Diederich, F. J. Am. Chem. Soc. 1990, 112, 1607.

75. Sidduri, A.; Budries, N.; Laine, R. M.; Knochel, P. Tetrahedron Lett. 1992, 33, 7515.

76. Cava, M. P.; Napier, D. R. J. Am. Chem. Soc. 1957, 79, 3606.

77. Cava, M. P.; Hwang, B. Tetrahedron Lett. 1965, 2297.

78. Nikokavouras, J.; Perry, A.; Vassilopoulos, G. Israel J. Chem. 1972, 10, 19.

79. (a) Brown, R. F. C.; Solly, R. K. Aust. J. Chem. 1966, 19, 1045. (b) Brown, R. F. C.; Eastwood, F. W.; McMullen, G. L. Chem. Commun. 1975, 328. (c) Gilchrist, T. L.; Rees, C. W.; Stanton, E. Chem. Commun. 1971, 801.

80. Forster, D.L.; Gilchrist, C.; Rees, C. W.; Stanton, E. Chem. Commun. 1971, 698.

81. (a) McOmie, J. F. W.; Perry, D. H. Chem. Commun. 1973, 248. (b) Jung, M. E.; Lowe, J. A. J. Org. Chem. 1977, 42, 2371. (c) Teim, O. A.; Jansen, R. B.; McOmie, J. F. W.; Perry, D. H. J. Chem. Soc., Perkin Trans. 1 1980, 1834. (d) Gould, K. J.; Hacker, N. P.; McOmie, J. F. W.; Perry, D. H. J. Chem. Soc., Perkin Trans. 1 1980, 1841. 